\title{
The cell biology of quiescent yeast - a diversity of individual scenarios
}

\author{
Isabelle Sagot* and Damien Laporte
}

\begin{abstract}
Most cells, from unicellular to complex organisms, spend part of their life in quiescence, a temporary non-proliferating state. Although central for a variety of essential processes including tissue homeostasis, development and aging, quiescence is poorly understood. In fact, quiescence encompasses various cellular situations depending on the cell type and the environmental niche. Quiescent cell properties also evolve with time, adding another layer of complexity. Studying quiescence is, above all, limited by the fact that a quiescent cell can be recognized as such only after having proved that it is capable of re-proliferating. Recent cellular biology studies in yeast have reported the relocalization of hundreds of proteins and the reorganization of several cellular machineries upon proliferation cessation. These works have revealed that quiescent cells can display various properties, shedding light on a plethora of individual behaviors. The deciphering of the molecular mechanisms beyond these reorganizations, together with the understanding of their cellular functions, have begun to provide insights into the physiology of quiescent cells. In this Review, we discuss recent findings and emerging concepts in Saccharomyces cerevisiae quiescent cell biology.
\end{abstract}

\section{KEY WORDS: S. cerevisiae, Quiescence, Aging}

\section{Introduction}

A wide range of cells spends the majority of their life in quiescence, a temporary non-proliferating cellular state. In the wild, unicellular organisms are most frequently quiescent, waiting for signals as diverse as the presence of specific nutrients, temperature or the level of oxygen to re-proliferate (Roche et al., 2017; Gray et al., 2004; De Virgilio, 2012; Rittershaus et al., 2013). In multi-cellular organisms, the archetype of quiescent cells are undoubtedly stem cells. Differentiated cells can be either quiescent or senescent, depending on the reversibility of the proliferation arrest. A cell is considered as senescent if it is metabolically active, but unable to re-proliferate (Campisi and d'Adda di Fagagna, 2007). Importantly, definitions of both senescence and quiescence are conjectural. Indeed, a cell that appears senescent may eventually re-enter proliferation under unrecognized environmental conditions. Likewise, quiescent cells have to face many challenges (Box 1), and cells that are quiescent at a given time can lose the capacity to re-proliferate. The reversible nature of each of these types of proliferation arrests can therefore be widely debated (O'Farrell, 2011; Terzi et al., 2016; Sun and Buttitta, 2017; Cheung and Rando, 2013; Velappan et al., 2017).

Centre National de la Recherche Scientifique, Université de Bordeaux-Institut de Biochimie et Génétique Cellulaires, UMR5095-33077 Bordeaux cedex, France.

*Author for correspondence (isabelle.sagot@ibgc.cnrs.fr)

(D) I.S., 0000-0003-2158-1783
What makes a quiescent cell? A central difficulty in characterizing these cells is inherently due to the definition of quiescence as 'a reversible absence of proliferation' because this encompasses highly diverse situations. Entry into quiescence is often associated with dramatic changes in metabolism, yet quiescent cells are not necessarily 'inactive' (Lemons et al., 2010; Valcourt et al., 2012), and dormancy, which is characterized by drastically reduced metabolic activities, can be considered as a specific form of quiescence (Roche et al., 2017; Rittershaus et al., 2013; Klosinska et al., 2011). In fact, the infinite variety of life, from bacteria living in extreme environmental conditions to plant meristems or dormant cancer cells, illustrates that the establishment of quiescence involves different adaptations depending on the cell type and its biotope. Even within the same organism, skin fibroblasts will not elicit the same processes as hematopoietic stem cells when they enter quiescence. This cell type-driven quiescence heterogeneity has been discussed in O'Farrell (2011). An additional layer of complexity comes from the observation that, for a given cell type, quiescence establishment takes different routes depending on the signal that had caused proliferation cessation. As an example, the transcription profiles of human fibroblasts are different when quiescence is triggered by contact inhibition, loss of adhesion or serum starvation (Coller et al., 2006). Similarly, in Saccharomyces cerevisiae, mRNA profiles, and the proteome and metabolome vary depending on the exhausted nutrient (Klosinska et al., 2011; Boer et al., 2010). Furthermore, even in a niche that may appear homogeneous, such as tissues or colonies, cells may face diverse micro-environments, including different oxygen supply or physical constraints (Cheung and Rando, 2013; Terzi et al., 2016; Rumman et al., 2015; Fiore et al., 2018). This heterogeneity is markedly exemplified by muscle (Sutcu and Ricchetti, 2018; Tierney and Sacco, 2016) and hematopoietic (Nakamura-Ishizu et al., 2014) stem cells, in which transcriptome variations have been measured at the single-cell level (Yang et al., 2017; van Velthoven et al., 2017). Finally, even for a particular cell type under apparent homogeneous environmental conditions, such as clonal $S$. cerevisiae populations grown to stationary phase in liquid medium, non-proliferating cells display heterogeneous properties (Gray et al., 2004; Palková et al., 2014; Miles and Breeden, 2016; Laporte et al., 2011, 2017, 2018). Hence, the endless diversity of cells and habitats preclude the existence of a universal quiescence program.

Another difficulty in studying quiescence is that practically, both in vivo and ex vivo, a quiescent cell can be undoubtedly qualified as such only after having proved that is it able to re-proliferate. This 'a-posteriori' identification dramatically limits the investigation of quiescent cell properties. Furthermore, in metazoans, it is particularly complicated to experimentally recapitulate quiescence, as this cellular state is regulated both by endogenous and systemic signals emanating from the entire tissue, organ or body. The physiology of ex vivo cell culture models are consequently questionable (O'Farrell, 2011; Rumman et al., 2015; Coller et al., 


\section{Box 1. Challenges faced by quiescent cells}

By definition, quiescent cells must preserve their ability to proliferate over periods ranging from days to decades. In other words, they have to face cellular aging. Quiescent cell longevity depends on their capacity to cope with detrimental events such as the accumulation of damaged macromolecules (de la Torre-Ruiz et al., 2015; Sampaio-Marques et al., 2014), including mutations (Gangloff et al., 2017; Gangloff and Arcangioli, 2017). The inability to handle these stresses ultimately leads to senescence and/or cell death. Facing cellular aging is not the only challenge of quiescent cells. Indeed, quiescence establishment, maintenance and exit, through the regulation of cell proliferation, are key steps involved in the development of multicellular organisms, and in major human pathologies, such as cancers or depletion of hematopoietic (Drabek et al., 2012), neural (Jones et al., 2015) and muscle (Chakkalakal et al., 2012) stem cells. In addition, upon proliferation resumption, quiescent cells have to give rise to healthy progeny, as abnormal descendants, particularly those with DNA damage, are potentially harmful for tissue homeostasis. Finally, exit from quiescence must be efficient. This is markedly true in case of microorganisms that are in competition for the same environmental niche, since the speed of this step ensures the prevalence of the species. Quiescence is therefore at the center of essential biological processes, such as development, aging, evolution and of pathological dysregulations of cell proliferation (Roche et al., 2017; Velappan et al., 2017; Cheung and Rando, 2013; Rumman et al., 2015; Dhawan and Laxman, 2015; O'Farrell, 2011; Sun and Buttitta, 2017).

2006). By contrast, S. cerevisiae, as a single-cell eukaryote, has been instrumental for studying quiescence. Margaret WernerWashburne pioneered this field and, in a visionary review, put forward the concept of a quiescence cycle. She proposed that proliferation-quiescence transitions are not simple 'aller-retour', but that quiescence establishment, maintenance and exit are specific processes (Gray et al., 2004), a view that is now widely accepted for multicellular models (Roche et al., 2017; Dhawan and Laxman, 2015; Rumman et al., 2015). In the same review, she proposed to harmonize the study of quiescence establishment in $S$. cerevisiae to glucose exhaustion conditions (Gray et al., 2004), a situation that might be close to what yeast cells may face in the wild, as phosphorus, sulfur and nitrogen starvations are less likely in natural yeast environmental niches (Goddard and Greig, 2015).

The purpose of the present Review is to scrutinize $S$. cerevisiae quiescence with the eyes of a cell biologist in the context of carbon exhaustion. Many excellent reviews have focused on genes and signaling cascades that link nutrients to quiescence establishment in $S$. cerevisiae (Fabrizio and Longo, 2003; De Virgilio, 2012; Mohammad et al., 2018; Gray et al., 2004; Herman, 2002; Zaman et al., 2008; Broach, 2012) and these aspects will thus not be discussed. Here, we will illustrate that the properties of quiescent cells vary depending on the individuals and evolve with time, thereby challenging once more the preconceived idea of quiescence uniformity.

\section{Quiescence entry and cell cycle arrest}

Quiescent cells are often considered as G1-arrested cells. Within $S$. cerevisiae populations in stationary phase following glucose exhaustion, $5-10 \%$ of the cells enter quiescence from another cell cycle phase than G1 (Laporte et al., 2011). Astonishingly, Schizosaccharomyces pombe, Cryptococcus neoformans and Tetrahymena pyriformis can enter quiescence in G1 or in G2, depending on external conditions (Takeo et al., 1995; Cameron and Bols, 1975; Costello et al., 1986). In mammals, it was proposed that upon quiescence entry, cells do not halt synchronously at the restriction point, but rather form a cohort of cells arrested as a continuum throughout G1 (Cooper, 1998, 2003; Matson and Cook, 2017). Furthermore, quiescent cells arrested in other phases than G1 have been observed in human carcinomas (Drewinko et al., 1984) and several cell lines (Baisch, 1988). Hence, a G1 arrest is not a strict prerequisite for quiescence establishment.

At the molecular level, the retinoblastoma protein $(\mathrm{Rb})$, a member of the so-called pocket protein family, and its interaction partners, the G1 cyclins and E2F transcription factor family, appear to be involved in quiescence establishment, but mutations that inactivate these cascades do not abolish quiescence entry in mice, flies and worms (Matson and Cook, 2017). In yeast, the Rb homologue Whi5, the histone deacetylase Rpd3, and the SCB binding factor (SBF)-binding proteins Msa1 and Msa2 have been shown to be involved in G1 arrest following nutrient starvation, but none of these factors are strictly required for quiescence survival (Miles and Breeden, 2016). Importantly, in both yeast and metazoans, an artificially prolonged arrest in G1 does not recapitulate the features of quiescence establishment (Martinez et al., 2004; Gasch et al., 2000; Radonjic et al., 2005; Coller et al., 2006). Thus, quiescent cells are not simply G1-arrested cells. The molecular links between quiescence establishment and cell cycle regulation are still unclear (Matson and Cook, 2017). In fact, fascinating studies indicate that cells decide to enter quiescence long before they actually stop proliferating (Box 2).

\section{Sorting of quiescent cells using physical properties}

Populations of yeast cells in stationary phase are composed of quiescent, senescent and dead cells, the relative proportion of which evolves with time and differs depending on the nature of the exhausted nutrient (Davidson et al., 2011; Klosinska et al., 2011; Werner-Washburne et al., 2012). If the 'unbudded' (G1 arrest) criterion alone is not sufficient to identify yeast quiescent cells, then how can we recognize them?

\section{Cell density}

The Werner-Washburne laboratory has shown that upon carbon exhaustion, a stationary phase population can be separated into two subfractions using a Percoll density gradient. The denser fraction is mostly composed of daughter cells and was designated as quiescent, because it showed better long-term survival than the less-dense

\section{Box 2. Cells decide to enter quiescence before completion of the 'last' cell cycle}

Are quiescence commitment and entry concomitant processes, or do cells anticipate quiescence entry well before they actually stop proliferating? Recent live-cell imaging studies have demonstrated that a few divisions before proliferation cessation, yeast cells integrate multiple metabolic signals that cross thresholds and trigger a cell fate decision (Argüello-Miranda et al., 2018). In fact, as early as in 1980, Lillie and Pringle observed that in yeast entering stationary phase, glycogen accumulation began well before glucose exhaustion (Lillie and Pringle, 1980). Indeed, glycogen stockpiling, which is crucial for yeast cell survival in quiescence, starts when half of the initial glucose remains in the medium, in other words when cells have one division left before glucose exhaustion (Lillie and Pringle, 1980). Thus, yeast anticipate quiescence entry before they exit the proliferation cycle. In human cells, it has been proposed that commitment to the next cell cycle is made at the end of the preceding cycle (Hitomi and Stacey, 1999; Chassot et al., 2008) and could involve a bifurcation of Cdk2 activity at the end of mitosis (Spencer et al., 2013; Matson and Cook, 2017; Dhawan and Laxman, 2015). Therefore, in both yeast and metazoans the decision to enter quiescence is taken before proliferation cessation. 
sub-population, which was called 'non-quiescent' (Allen et al., 2006). However, this dichotomy may be too simplistic.

Is cell density relevant to quiescence? Either, there is an active process that specifically and exclusively makes only dense cells quiescent (Davidson et al., 2011; Werner-Washburne et al., 2012). Alternatively, the difference in cell density is a consequence of properties specifically found in a subset of daughter cells, but unrelated to quiescence. Glycogen and trehalose contents correlate with cell density, since mutants unable to synthetize these sugars do not separate into two subfractions (Shi et al., 2010). Despite this, the Breeden laboratory has found that trehalose accumulation is necessary but not sufficient to increase cell density ( $\mathrm{Li}$ et al., 2013). Thus, the molecular basis for the physical separation of stationary phase population into two subpopulations with different density is still unclear. In fact, lipids, which accumulate upon proliferation cessation, have a major influence on cell density (Sandager et al., 2002; Singh and Li, 2017; Graef, 2018) and may be involved in the above-described cell partitioning. In addition, daughter cells are much smaller than mother cells (Jorgensen and Tyers, 2004). Hence, population subfractionation using a density gradient may just be a way to sort cells with a given trehalose and lipid content in a given volume range, a specific combination of parameters that would mostly be found in some daughter cells. Although these cells have a good survival rate in quiescence, this does not imply that cells that do not meet these criteria are not quiescent.

\section{Cell replicative age}

The above model posits that only daughter cells are bona fide quiescent cells and that mother cells are not (Davidson et al., 2011). The corollary is that replicative age [the number of divisions a cell has undergone (Mortimer and Johnston, 1959)], strongly impacts on the ability of a cell to face chronological age [the time a cell is able to survive in quiescence (Fabrizio and Longo, 2003)]. In both yeast and human fibroblasts, chronological age is known to influence cell replicative age capacities, the longer the time in quiescence, the less divisions a cell can undergo upon proliferation resumption (Ashrafi et al., 1999; Munro et al., 2001; Marthandan et al., 2014). Recently, we have demonstrated that replicative age does not influence either the ability of a cell to enter quiescence (Laporte et al., 2018) or its efficiency at exiting quiescence (Laporte et al., 2017), at least for 7-day-old mother cells that had undergone less than 15 divisions. Therefore, more than $99 \%$ of the mother cells found in a 7-day-old population are quiescent. This remains to be investigated for cells that have spent a prolonged time in stationary phase.

\section{Cell size}

Recently, stationary phase populations have been separated into subpopulations according to cell size (Svenkrtova et al., 2016). It was found that, with time, very small cells ( 2 to $4 \mu \mathrm{m}$ in diameter) displayed a reduced ability to re-proliferate (Svenkrtova et al., 2016). In agreement, at the population scale, we found that very small cells (less than $30 \mathrm{fl}$ in volume, or $\sim 2.5 \mu \mathrm{m}$ in diameter) have a slightly increased susceptibility to enter senescence. However, after having set aside senescent cells, cell volume per se does not impinge on the ability of individual cell to survive in quiescence, at least after 7 days (Laporte et al., 2018). Nonetheless, cell volume does influence quiescence exit efficiency, as cells exiting quiescence must reach a 'critical size' before entering $\mathrm{S}$ phase, just as proliferating G1 cells do (Laporte et al., 2017). Thus, large quiescent cells generally emit a bud faster than small quiescent cells, because upon refeeding, they do not need to grow as much to reach the size needed for quiescence exit (Laporte et al., 2017). In addition, we have observed that within the same volume range, individual cells can re-enter proliferation with a different efficiency (Laporte et al., 2017). Similarly, in muscle satellite cells, an 'alerting' mechanism has been proposed to 'help' a subpopulation of cells to respond more rapidly under injury conditions by enhancing their efficiency to exit quiescence (Rodgers et al., 2014). Thus, in yeast and mammals, quiescent cells with different responsiveness do exist.

Taken together, by separating non-dividing cell populations using some of their physical properties, it is possible to enrich a subpopulation in quiescent cells. These methods may be of interest when a large number of cells is required, such as for western blots or 'omics' approaches, but it is important to realize that the obtained results are only valid for a subset of quiescent cells. As pinpointed by Margaret Werner-Washburne, the major problem of these methods is that they assign the property of being quiescent to a subpopulation. However, quiescence is only meaningful at the individual cell level (Werner-Washburne et al., 2012). This is not just semantics, and one has to keep in mind that quiescent cell-specific properties that are credited using subfractionation may not be generalizable to all quiescent cells, or even worse, not be specific to quiescence, but instead specific to the subpopulation of cells that have been selected on criteria that may, however, be unrelated to quiescence.

\section{Reorganization of cellular machineries upon proliferation cessation}

Before the turn of the millennium, very little was known about nondividing yeast cells at the cell biology level (Gray et al., 2004), except that they had a thick cell wall (Elliott and Futcher, 1993; de Nobel et al., 1990) and condensed chromosomes, as observed by DAPI staining (Piñon, 1978). Since then, the remodeling of a striking variety of cellular machineries and organelles have been observed upon proliferation cessation in S. cerevisiae (Fig. 1; Table S1).

\section{Actin cytoskeleton}

In proliferating cells, the actin cytoskeleton is a highly dynamic network composed of actin cables, which serve as tracks for secretory vesicles, actin patches, which sustain endocytosis, and an actin ring, which is involved in cytokinesis (Mishra et al., 2014). Upon proliferation cessation, all these structures vanish and new actin-filament-containing spheroids, named actin bodies, are assembled (Sagot et al., 2006). Actin bodies contain specific actin-binding proteins and are composed of astonishingly stable actin filaments. The molecular mechanism involved in actin body formation is still unknown. However, it is known that mutants that cannot assemble these structures are unable to survive in quiescence (Sagot et al., 2006). Although the physiological functions of actin bodies remain obscure, they may be actin reservoirs that can be readily mobilized upon proliferation resumption (Sagot et al., 2006). Interestingly, the formation of spheroid actin structures that resemble actin bodies have been observed upon proliferation cessation in S. pombe (Laporte et al., 2015), in plants (Poulter et al., 2010; Wilkins et al., 2015) and in non-dividing endothelial cells (Jensen and Larsson, 2004).

\section{Microtubules}

Microtubules are dynamic tubulin polymers that are crucial for several processes, including chromosome segregation (Muroyama and Lechler, 2017; Winey and Bloom, 2012). In S. cerevisiae, upon proliferation cessation, cytoplasmic microtubules disappear and 


\section{Proliferating G1 Non-proliferating cells cells}

Actin cytoskeleton

Cables and patches

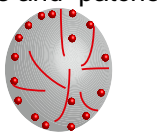

Proteasome

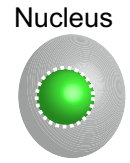

Enzymes

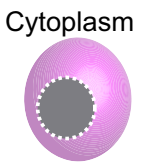

Microtubules

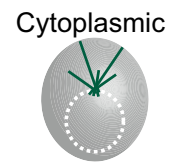

Stress granules

Cytoplasm and nucleus

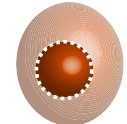

Mitochondria

Cytoplasmic network

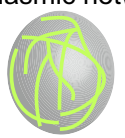

Telomeres

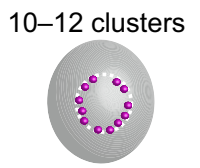

Hsp90

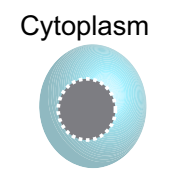

P-bodies and enzymes

Cytoplasm

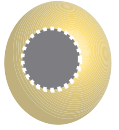

Hsp42/Hos2

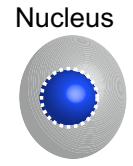

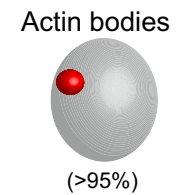

PSG
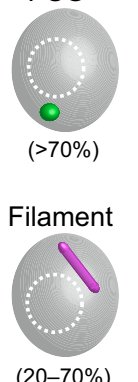

Nuclear bundle

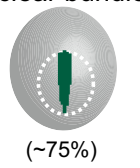

Foci

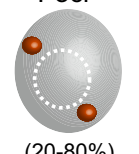

(20-80\%)

Cortical vesicles
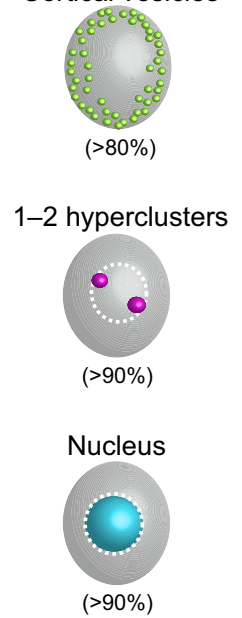

Foci

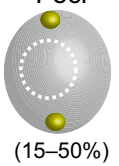

SPG

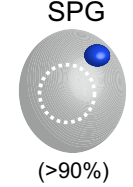

Fig. 1. Cellular machinery and organelle reorganizations upon proliferation cessation. Side-by-side representation of some cellular machineries or organelles in proliferating $\mathrm{G} 1$ cells and in non-proliferating cells (carbon exhaustion). White dotted circles represent the nuclear membrane. Numbers are the percentage of cells displaying the indicated remodeling within a 7-day-old stationary phase population.

nuclear microtubules elongate from the spindle pole body (SPB), the yeast equivalent of the centrosome, to form a long monopolar bundle that traverses the entire nucleus (Laporte et al., 2013). Intriguingly, microtubules composing this bundle are very stable. Furthermore, mutants that cannot assemble this structure precociously die upon carbon exhaustion, suggesting that it may be required for survival of quiescent cells (Laporte et al., 2013). Microtubule stabilization has been described in quiescent S. pombe (Laporte et al., 2015), in serum-deprived fibroblasts (Danowski, 1998) and during the centrosome migration seen upon assembly of the primary cilia in human retina epithelial cells entering quiescence (Pitaval et al., 2017). The physiological 'raison d'être' of microtubule stabilization in quiescent cell remains a mystery. An appealing hypothesis might be that stable microtubules sequester critical cell-cycle-regulating factors (Zhang et al., 2015; Ruiz-Miró et al., 2011; Silva and Cassimeris, 2013), thereby maintaining cells in a quiescent state.

\section{Nucleus}

In quiescent cells, the formation of a stable nuclear microtubule bundle radically transforms the Rabl-like nucleus organization typically found in yeast G1 cells (Taddei et al., 2010). The nucleolus is no longer found opposite to the SPB, but rather adjacent to the microtubule bundle. The centromeres, together with kinetochores, stay attached to microtubule plus-ends and are mostly found at the microtubule bundle tip (Laporte et al., 2013; Laporte and Sagot, 2014). More globally, the genome undergoes massive topological rearrangements, including chromosome condensation (Rutledge et al., 2015; Guidi et al., 2015). Telomeres, which localize to a dozen of foci in G1 cells, regroup into one to two hyper-clusters (Guidi et al., 2015; Rutledge et al., 2015; Laporte et al., 2016; Laporte and Sagot, 2014). This clustering relies on the SIR complex and the chromosome condensation machinery (Laporte et al., 2016; Rutledge et al., 2015; Guidi et al., 2015), but appears to be non-essential for cell survival in quiescence, at least after 7 days (Laporte et al., 2016). Whether all these nuclear reorganizations influence gene expression upon proliferation cessation remains an open question.

\section{Mitochondria}

In S. cerevisiae, mitochondrial dysfunctions affect the ability of a cell to deal with both replicative and chronological age (Fabrizio and Longo, 2003; Martinez et al., 2004; Trancíková et al., 2004; Bonawitz et al., 2006; Aerts et al., 2009; Ocampo et al., 2012; Beach et al., 2015). Proliferating yeast cells exhibit a dynamic network of mitochondrial tubules (Friedman and Nunnari, 2014). We recently reported that this network undergoes a massive remodeling upon proliferation cessation (Laporte et al., 2018). Quiescent yeast cells exhibit numerous small and immobile cortical mitochondrial vesicles. In contrast, cells that will enter senescence display one or two big globular mitochondria, a phenotype that is associated with impaired oxidative phosphorylation (Laporte et al., 2018). Interestingly, abnormally enlarged mitochondrial structures have been observed in replicatively old yeast cells (Scheckhuber et al., 2007; Veatch et al., 2009; McFaline-Figueroa et al., 2011; Hughes and Gottschling, 2012; Fehrmann et al., 2013), as well as in many 
aging models, including the mouse myocardium (Coleman et al., 1987), human fibroblasts (Yoon et al., 2006) and Medicago truncatula (Zottini et al., 2006). Further, a massive remodeling from tubules to donut-shaped mitochondria has been recently reported in glioblastoma stem-like cells entering quiescence (Aulestia et al., 2018). Thus, the mitochondrial morphology appears to respond to the cellular state in many eukaryotes.

\section{mRNA granules}

Upon proliferation cessation, RNA-processing enzymes relocalize and encapsulate translationally repressed mRNAs to form P-bodies and stress granules. Although they contain an overlapping set of enzymes (Kedersha and Anderson, 2002; Anderson and Kedersha, 2009; Balagopal and Parker, 2009), P-bodies and stress granules are distinct structures. P-bodies are mostly composed of proteins regulating mRNA decay (Parker and Sheth, 2007; Sheth and Parker, 2003), whereas stress granules enclose proteins involved in translation and, as such, could be mRNA storage particles (Yamasaki and Anderson, 2008). In yeast, P-bodies form upon glucose exhaustion in a protein kinase A (PKA)-dependent manner and are required for cell survival (Ramachandran et al., 2011). Stress granules assemble later, independently of PKA activity (Shah et al., 2013, 2014), and their formation may involve phase separation (Riback et al., 2017). Importantly, ribonucleoprotein granules have been observed in many environmental conditions and in numerous cellular models, including worms, flies and mammals, but their physiological function is still under debate (Buchan, 2014; Sfakianos et al., 2016).

\section{Proteasome}

When cells enter quiescence, the proteasome moves from the nucleus into foci called proteasome storage granules (PSGs) (Laporte et al., 2008). PSG formation is a multistep process (Enenkel, 2018). In response to a drop in intracellular $\mathrm{pH}$ (Peters et al., 2013), proteasomes first exit the nucleus, most probably in the form of separated 19S and 20S sub-complexes (Nemec et al., 2017). Damaged proteasomes are directed to an insoluble protein aggregates deposit, termed IPOD, (Peters et al., 2016), which is closely associated with the vacuole (Kaganovich et al., 2008; Spokoini et al., 2012), where they may be degraded (Marshall et al., 2016). Intact proteasome sub-complexes are independently directed to mature PSGs (Marshall and Vierstra, 2018). A high-throughput screen has revealed that as many as 45 proteins are required for PSG formation ( $\mathrm{Gu}$ et al., 2017), including proteasome accessory proteins, such as Blm10 or Spg5 (Marshall and Vierstra, 2018), and proteasome-modifying enzymes, such as the NatB acetylation complex (van Deventer et al., 2015). We proposed that PSGs may be a reservoir that protect proteasomes from degradation (Laporte et al., 2008), an hypothesis elegantly demonstrated by the Vierstra laboratory (Marshall and Vierstra, 2018). At the cellular level, PSGs are important for both cell survival in quiescence and quiescence exit efficiency (Marshall and Vierstra, 2018; Gu et al., 2017; Weberruss et al., 2013). Finally, PSGs have been observed in fission yeast (Laporte et al., 2008) and in plants (Marshall and Vierstra, 2018), suggesting that this structure may be conserved among eukaryotes.

\section{Heat-shock proteins and metabolic enzymes}

Following nutrient exhaustion, the synthesis of many heat-shock proteins is upregulated and their concomitant relocalization is well-established. Some of them, such as proteins from the Hsp90 family, p23/Sba1 and the Hsp70 family protein Ssa1 relocalize from the cytoplasm into the nucleus in a karyopherin-dependent manner. This accumulation appears to be important for quiescence exit (Tapia and Morano, 2010; Chughtai et al., 2001). In contrast, Hsp42 and Hsp26 form cytosolic foci and trigger the relocalization of other enzymes including the histone deacetylase Hos2 (Liu et al., 2012). In fact, a high-throughput screen has identified more than 180 metabolic enzymes that concentrate into cytoplasmic foci or filaments upon proliferation cessation (Narayanaswamy et al., 2009). This includes enzymes of the purine and pyrimidine synthesis pathways, proteins involved in translation, and many kinases (Narayanaswamy et al., 2009; Noree et al., 2010; Shah et al., 2014), with some of these relocalizations being conserved in bacteria, flies and humans (O'Connell et al., 2012, 2014). Importantly, colocalization experiments have demonstrated that these proteins do not relocalize into the same foci, but rather into distinct structures whose assembly is not necessarily concomitant (Shah et al., 2014). The cellular functions of these intracellular structures are still unclear, but they may provide functional advantages, such as channeling of substrates or improved co-regulation. However, the formation of multi-enzyme assemblies of proteins involved in a given metabolic pathway does not appear to be the general rule (O'Connell et al., 2014). Furthermore, a close coupling between enzyme activity and filament formation has been reported (Noree et al., 2014). Overall, these structures may be storage modules, in which proteins are protected from degradation, but remain readily mobilizable when they are needed, such as upon substrate replenishment, cell stress or proliferation resumption.

\section{Reversibility}

Upon quiescence exit, all the above-mentioned reorganizations are not maintained in the mother cell, nor are they transmitted to the daughter cell. Indeed, all these structures disappear upon proliferation resumption before new bud emergence. Actin body disassembly occurs within seconds upon cell refeeding (Sagot et al., 2006; Laporte et al., 2011), while relocalization of proteins from PSGs into the nucleus takes a few minutes (Laporte et al., 2008), as does mitochondrial tubule re-formation (Laporte et al., 2018). Nuclear microtubule shortening takes about an hour (Laporte et al., 2013), and P-bodies and stress granules dissociate gradually, component after component, in 90 min (Shah et al., 2014; Brengues and Parker, 2007). The majority of these dismantling events are independent of de novo protein synthesis (Shah et al., 2014; Liu et al., 2012; Sagot et al., 2006; Laporte et al., 2008). The disassembly of actin bodies and PSGs is triggered by glucose metabolization through the glycolytic pathway (Laporte et al., 2011). Furthermore, dissociation of P-bodies and stress granules does not involve protein degradation (Shah et al., 2014). The mechanisms underlying the formation of quiescent-cell-specific structures are difficult to tackle given the time they take to assemble (often several days). By contrast, their dissociation occurs shortly after cell refeeding and, as such, may be easier to elucidate at the molecular level.

As a conclusion, a vast number of reorganizations have been observed upon proliferation cessation. In fact, three types of remodeling can be distinguished based on their complexity. The first category encompasses structures composed of one or only a few enzymes by a given metabolic pathway. The second concerns structures with a complex architecture, such as microtubule bundles or PSGs. The third entails rearrangements at the scale of an organelle. As the above-described structures are organized edifices that are dismantled within minutes after the cells have been re-fed, 
they are obviously not simple unstructured aggregates of nonfunctional proteins. Besides, we can speculate that the reorganizations reported to date are just the tip of the iceberg and that many more are still to be discovered.

\section{Beyond machinery reorganizations}

Following the observations of the above-presented reorganizations, many questions have emerged, and below we discuss what we consider to be the most salient ones with regard to a better understanding of quiescence.

\section{Environmental condition specificity}

As a start, we can wonder whether a given reorganization is specific for proliferation cessation upon glucose exhaustion, or whether it can also occur under other environmental conditions. The formation of P-bodies have been observed in response to many cellular stresses, including high salt, temperature and various nutrient starvations (Sheth and Parker, 2003; Teixeira et al., 2005; Brengues et al., 2005). PSGs do not form upon nitrogen starvation, which instead directs the proteasome for degradation by the vacuole (Waite et al., 2016; Marshall et al., 2016; Marshall and Vierstra, 2018). In fact, when nitrogen is exhausted, cells undergo massive autophagy that prevents the formation of actin bodies (Laporte et al., 2011) and ultimately leads to cell death. Nitrogen starvation further induces selective mitophagy (Camougrand et al., 2008), thus precluding the formation of mitochondrial vesicles (Laporte et al., 2018). Hence, each individual structure has its own behavior. Importantly, a remodeling that occurs under a unique specific condition is not less interesting than one found in multiple environmental scenarios, as both may shed light on cellular needs (Marshall and Vierstra, 2018).

\section{Physical constraints and slow-down of metabolism}

Another critical question is to decipher whether the observed reorganizations are the result of changes in the physical properties of cellular compartments. PSG formation has been linked to the drop in intracellular $\mathrm{pH}$ that occurs upon glucose exhaustion (Peters et al., 2013). Similarly, the formation of some enzymecontaining filaments are driven by a self-assembly mechanism that is related to both cytoplasm acidification and an increase in molecular crowding (Petrovska et al., 2014). In fact, a drop in intracellular $\mathrm{pH}$ has been shown to induce a transition from a fluid-like to a solid-like state of the cytoplasm (Munder et al., 2016) and to participate in the phase-separation that may be underlying stress granule formation (Riback et al., 2017). However, the decrease in diffusional mobility of cellular structures is not necessarily associated with a drop in intracellular $\mathrm{pH}$ and could rather be linked to a reduction in cell volume, which severely alters the biophysical properties of both the nucleus and the cytoplasm (Joyner et al., 2016). Importantly, intracellular confinement appears to be unrelated to a metabolic slowdown that triggers a drop in ATP concentration (Joyner et al., 2016). Even though the effect of ATP concentration on the reorganization of each cellular machinery upon quiescence establishment remains to be investigated, ATP replenishment is neither necessary nor sufficient for actin body mobilization upon quiescence exit (Laporte et al., 2011). Furthermore, a drop in the intracellular concentration of GTP does not lead to microtubule stabilization, and therefore cannot be the cause of microtubule stabilization in quiescence (Laporte et al., 2015). Thus, once again, the impact of both the metabolic and biophysical environment depends on the cellular machinery of interest.

\section{Specific protein pathways}

Several reorganizations are driven by specific molecular pathways. As an example, PSG formation depends on acetylases and at least 40 other proteins (Gu et al., 2017; van Deventer et al., 2015; Weberruss et al., 2013; Saunier et al., 2013). Actin body assembly requires specific actin-binding proteins such as fimbrin (Sagot et al., 2006). Similarly, several microtubule-associated proteins are needed for nuclear microtubule bundle formation (Laporte et al., 2013). Further, some reorganizations may depend on other rearrangements. The formation of the stable microtubule bundle inside the quiescent yeast nucleus causes the relocalization of both the nucleolus and the centromere-kinetochore complexes, but is independent of telomere hyper-clustering (Laporte et al., 2013, 2016; Laporte and Sagot, 2014).

In fact, the assembly of quiescent-cell-specific structures most likely depends on a combination of several parameters, including biophysical constraints, metabolic changes and interactions with specific protein partners. One obvious example is telomere hyperclustering in quiescence, which most likely results from a combination of nuclear viscosity increase (Joyner et al., 2016), the stockpiling of the silencing protein Sir3, which acts as a glue at sub-telomeric loci (Laporte et al., 2016; Ruault et al., 2011; Guidi et al., 2015), and chromatin hyper-condensation (Rutledge et al., 2015). All these events converge to reduce the exploratory volume of telomeres, thereby increasing their probability of clustering.

\section{Is there a quiescence-specific marker?}

If a plethora of reorganizations have been observed upon proliferation cessation, one critical question is to know if they are specific for quiescence. In other words, can we use one of them as a quiescence marker? Some reorganizations, such as P-bodies, are not specific to proliferation cessation (Sheth and Parker, 2003). Others can be found in both quiescent and senescent cells, for instance actin bodies, and as such may be more general markers of proliferation cessation (Laporte et al., 2018). Furthermore, some structures are assembled only in a subset of quiescent cells, such as enzymecontaining foci (Noree et al., 2010). With time, quiescent cells progressively lose their capacity to re-proliferate. One can envision that a reorganization that is rarely found at early time points may be crucial for cell survival in quiescence in the long-run. (Fig. 2). Addressing the requirement for quiescence survival for a given structure awaits experiments done at the individual cell level. To date, none of the rearrangement observed upon proliferation cessation has been found to be strictly specific for quiescence and found in all quiescent cells.

\section{Quiescence deepening - adding time in the game}

Finding a reliable quiescence marker is even more complicated given that cell properties change with the time spent in quiescence. In fibroblasts, transcriptome analyses have shown that most of the up- or down-regulated genes are induced or repressed more strongly after 20 days than after 4 days of quiescence (Coller et al., 2006). Furthermore, WI-38 cell cultures deprived of serum for weeks re-enter the cell cycle more slowly than those that have been starved for only a few days (Augenlicht and Baserga, 1974; Soprano, 1994). In $S$. pombe, the longer the nitrogen starvation period, the slower populations resume proliferation ( $\mathrm{Su}$ et al., 1996). These observations suggest that an arrest for a prolonged period of time results in a 'deepening' of quiescence. However, these experiments measure the overall proliferation resumption of a cell population, which is the combination of both the number of cells capable to exit quiescence and the efficiency of each cell to re-proliferate. To 


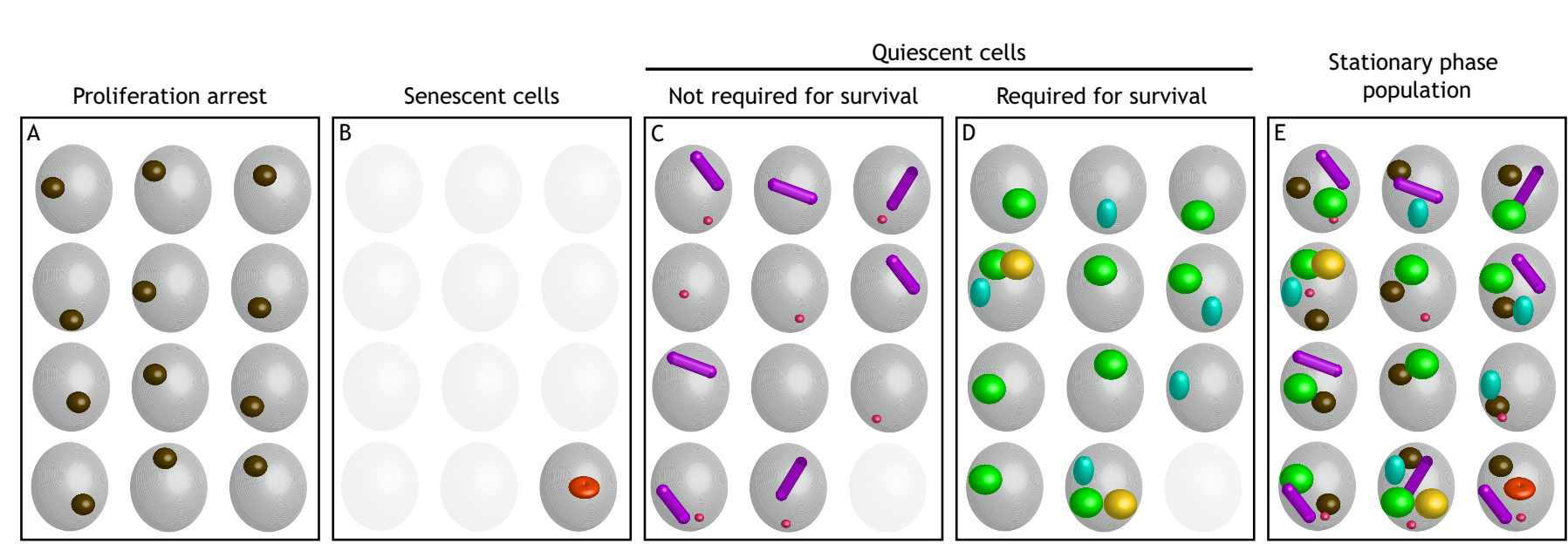

Fig. 2. Non-proliferating cells display a variety of individual features. (A) Cellular structure (brown balls) assembled upon proliferation arrest and found in both senescent and quiescent cells (e.g. actin bodies). (B) Cellular reorganizations (red spheroids) found only in senescent cells (such as globular mitochondria). (C,D) Quiescent-cell-specific cellular reorganizations (violet cylinders, small red spheres) not required for cell survival in quiescence (like telomere hyper-clusters) (C), and quiescent-cell-specific cellular reorganizations (green and yellow spheres, blue ovals) required for cell survival in quiescence

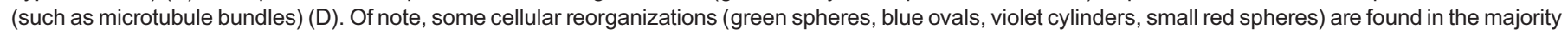

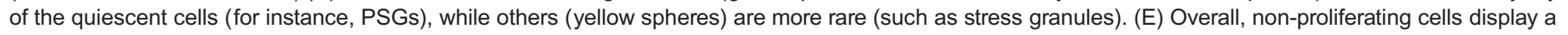
plethora of different properties.

circumvent this caveat, it is now possible to study quiescence exit efficiency at the individual cell level using microscope pads or microfluidic devices. In doing so, we have shown that the longer the time in quiescence, the more time a yeast cell needs to re-proliferate (Laporte et al., 2017). This decrease in the speed of quiescence exit may notably depend on intracellular trehalose (Laporte et al., 2017), a sugar that fuels the return into proliferation and whose intracellular level progressively decreases as cells age (Shi et al., 2010; Samokhvalov et al., 2004; Lillie and Pringle, 1980; Kyryakov et al., 2012; Cao et al., 2016). Furthermore, as quiescent cells age, they may accumulate damages that could affect not only quiescence exit efficiency, but also result in their transitioning into senescence. In fact, some quiescent cells may enter senescence more rapidly than others. Indeed, we have shown that respiratory-deficient cells lose their capacity to re-proliferate within a few days, whereas wild-type cells can stay quiescent for months (Laporte et al., 2018) or maybe even for centuries (de Virgilio, 2012).

As time influences cell survival in quiescence, we can wonder whether the reorganizations observed in 'young' quiescent cells are maintained with age and are preserved when quiescent cells transition into senescence, or whether they vanish when cells lose their capacities to re-proliferate (Fig. 3). Clarifying these points awaits techniques that will allow for long-term imaging of individual cells.

\section{Conclusions}

Upon proliferation cessation, individual yeast cells reorganize many cellular machineries. Some reorganizations take place in the majority of the cells, whereas others are rather rare. This gives rise to a heterogeneous population of cells with differing individual properties and begs the question of whether one of these rearrangements could be used as a yeast quiescence marker. Such a rearrangement should be found only in quiescent cells, in all quiescent cells and at any given time in quiescence. Given the heterogeneity of the properties of individual quiescent yeast cells, it is most likely illusory to find such an infallible yeast quiescence marker and even more unrealistic that a quiescence marker conserved in all eukaryotes can be uncovered.

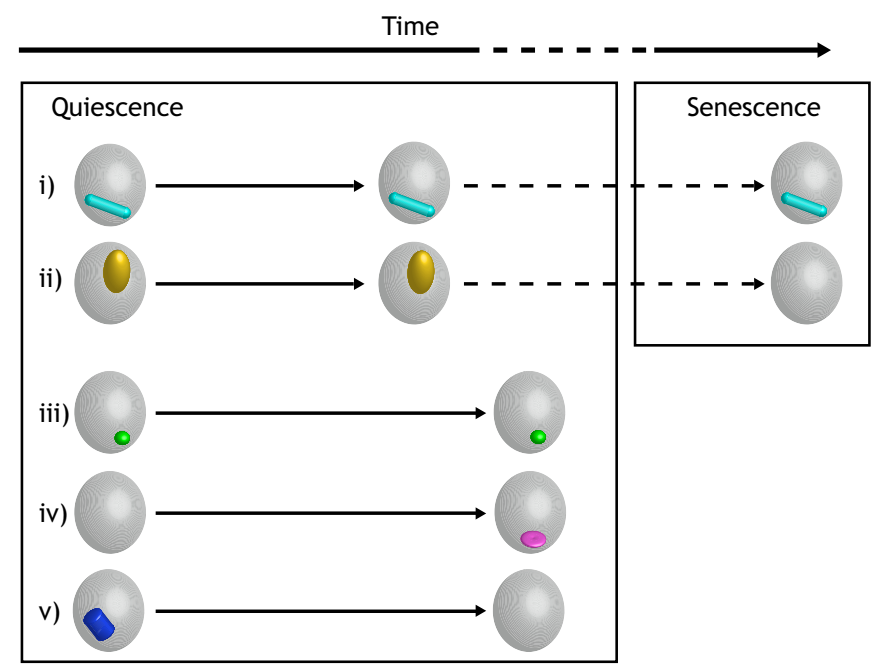

Fig. 3. Individual features of quiescent cells may evolve with the time spent in quiescence and upon transition to senescence. (i) A quiescentcell-specific structure that is maintained when quiescent cells transit into senescence (blue cylinder). (ii) A quiescent-cell-specific structure that is disassembled when quiescent cells transit into senescence (yellow oval). (iii) A structure assembled upon quiescence entry and maintained throughout quiescence (green dot). (iv) A structure assembled only in late quiescence (pink spheroid). (v) A structure assembled upon quiescence entry that disassembles in late quiescence (dark blue cylinder).

To shed further light on the cell biology of quiescence, the key may be to understand the physiology that underpins each of the specific cellular rearrangements. A first level of knowledge would be to decipher the molecular mechanisms underlying their formation and disassembly. A second level would be to elucidate the physiological function of each cellular rearrangement and to determine whether it is required for quiescence establishment, quiescence long-term survival and/or quiescence exit efficiency. A third level would be to test whether a given reorganization is crucial for the survival of a specific cell type in a given environment or is common to several cell types and/or several microenvironmental niches. 
Quiescent cell biology is an exciting young field. Collectively, works over the past two decades have revealed that quiescent cells are not 'insignificant frozen G1 cells', but are rather at the heart of major biology processes and display specific features that vary not only with regard to the cell type and the micro-environment, but also at the scale of an individual cell.

\section{Acknowledgements}

We express our profound gratitude to B. Daignan-Fornier and J.-P. Javerzat for precious discussions and comments on this manuscript.

\section{Competing interests}

The authors declare no competing or financial interests.

\section{Funding}

D.L. and I.S. are supported by the Université de Bordeaux and the Centre National de la Recherche Scientifique.

\section{Supplementary information}

Supplementary information available online at

http://jcs.biologists.org/lookup/doi/10.1242/jcs.213025.supplemental

\section{References}

Aerts, A. M., Zabrocki, P., Govaert, G., Mathys, J., Carmona-Gutierrez, D. Madeo, F., Winderickx, J., Cammue, B. P. A. and Thevissen, K. (2009). Mitochondrial dysfunction leads to reduced chronological lifespan and increased apoptosis in yeast. FEBS Lett. 583, 113-117.

Allen, C., Büttner, S., Aragon, A. D., Thomas, J. A., Meirelles, O., Jaetao, J. E., Benn, D., Ruby, S. W., Veenhuis, M., Madeo, F. et al. (2006). Isolation of quiescent and nonquiescent cells from yeast stationary-phase cultures. J. Cell Biol. 174, 89-100

Anderson, P. and Kedersha, N. (2009). RNA granules: post-transcriptional and epigenetic modulators of gene expression. Nat. Rev. Mol. Cell Biol. 10, 430-436.

Argüello-Miranda, O., Liu, Y., Wood, N. E., Kositangool, P. and Doncic, A. (2018). Integration of multiple metabolic signals determines cell fate prior to commitment. Mol. Cell 71, 733-744.e11.

Ashrafi, K., Sinclair, D., Gordon, J. I. and Guarente, L. (1999). Passage through stationary phase advances replicative aging in Saccharomyces cerevisiae. Proc. Natl. Acad. Sci. USA 96, 9100-9105.

Augenlicht, L. H. and Baserga, R. (1974). Changes in the G0 state of WI-38 fibroblasts at different times after confluence. Exp. Cell Res. 89, 255-262.

Aulestia, F. J., Néant, I., Dong, J., Haiech, J., Kilhoffer, M.-C., Moreau, M. and Leclerc, C. (2018). Quiescence status of glioblastoma stem-like cells involves remodelling of $\mathrm{Ca} 2+$ signalling and mitochondrial shape. Sci. Rep. 8, 9731.

Baisch, H. (1988). Different quiescence states of three culture cell lines detected by acridine orange staining of cellular RNA. Cytometry 9, 325-331.

Balagopal, V. and Parker, R. (2009). Polysomes, P bodies and stress granules: states and fates of eukaryotic mRNAs. Curr. Opin. Cell Biol. 21, 403-408.

Beach, A., Leonov, A., Arlia-Ciommo, A., Svistkova, V., Lutchman, V. and Titorenko, V. I. (2015). Mechanisms by which different functional states of mitochondria define yeast longevity. Int. J. Mol. Sci. 16, 5528-5554.

Boer, V. M., Crutchfield, C. A., Bradley, P. H., Botstein, D. and Rabinowitz, J. D. (2010). Growth-limiting intracellular metabolites in yeast growing under diverse nutrient limitations. Mol. Biol. Cell 21, 198-211.

Bonawitz, N. D., Rodeheffer, M. S. and Shadel, G. S. (2006). Defective mitochondrial gene expression results in reactive oxygen species-mediated inhibition of respiration and reduction of yeast life span. Mol. Cell. Biol. 26, 4818-4829.

Brengues, M. and Parker, R. (2007). Accumulation of polyadenylated mRNA, Pab1p, elF4E, and elF4G with P-bodies in Saccharomyces cerevisiae. Mol. Biol. Cell 18, 2592-2602.

Brengues, M., Teixeira, D. and Parker, R. (2005). Movement of eukaryotic mRNAs between polysomes and cytoplasmic processing bodies. Science 310, 486-489.

Broach, J. R. (2012). Nutritional control of growth and development in yeast. Genetics 192, 73-105.

Buchan, J. R. (2014). mRNP granules. Assembly, function, and connections with disease. RNA Biol. 11, 1019-1030.

Cameron, I. L. and Bols, N. C. (1975). Effect of cell population density on G2 arrest in Tetrahymena. J. Cell Biol. 67, 518-522.

Camougrand, N., Kissová, I., Salin, B. and Devenish, R. J. (2008). Monitoring mitophagy in yeast. Methods Enzymol. 451, 89-107.

Campisi, J. and d'Adda di Fagagna, F. (2007). Cellular senescence: when bad things happen to good cells. Nat. Rev. Mol. Cell Biol. 8, 729-740.

Cao, L., Tang, Y., Quan, Z., Zhang, Z., Oliver, S. G. and Zhang, N. (2016). Chronological lifespan in yeast is dependent on the accumulation of storage carbohydrates mediated by Yak1, Mck1 and Rim15 kinases. PLoS Genet. 12 e1006458.

Chakkalakal, J. V., Jones, K. M., Basson, M. A. and Brack, A. S. (2012). The aged niche disrupts muscle stem cell quiescence. Nature 490, 355-360.

Chassot, A.-A., Lossaint, G., Turchi, L., Meneguzzi, G., Fisher, D., Ponzio, G. and Dulic, V. (2008). Confluence-induced cell cycle exit involves pre-mitotic CDK inhibition by p27(Kip1) and cyclin D1 downregulation. Cell Cycle Georget. Tex. 7 , 2038-2046.

Cheung, T. H. and Rando, T. A. (2013). Molecular regulation of stem cell quiescence. Nat. Rev. Mol. Cell Biol. 14, 329-340.

Chughtai, Z. S., Rassadi, R., Matusiewicz, N. and Stochaj, U. (2001). Starvation promotes nuclear accumulation of the hsp70 Ssa4p in yeast cells. J. Biol. Chem. 276, 20261-20266.

Coleman, R., Silbermann, M., Gershon, D. and Reznick, A. Z. (1987). Giant mitochondria in the myocardium of aging and endurance-trained mice. Gerontology 33, 34-39.

Coller, H. A., Sang, L. and Roberts, J. M. (2006). A new description of cellular quiescence. PLoS Biol. 4, e83.

Cooper, S. (1998). On the proposal of a G0 phase and the restriction point. FASEB J. Off. Publ. Fed. Am. Soc. Exp. Biol. 12, 367-373.

Cooper, S. (2003). Reappraisal of serum starvation, the restriction point, G0, and G1 phase arrest points. FASEB J. Off. Publ. Fed. Am. Soc. Exp. Biol. 17, 333-340.

Costello, G., Rodgers, L. and Beach, D. (1986). Fission yeast enters the stationary G0 state from either mitotic G1 or G2. Curr. Genet. 11, 119-125.

Danowski, B. A. (1998). Microtubule dynamics in serum-starved and serumstimulated Swiss 3T3 mouse fibroblasts: implications for the relationship between serum-induced contractility and microtubules. Cell Motil. Cytoskeleton 40, 1-12.

Davidson, G. S., Joe, R. M., Roy, S., Meirelles, O., Allen, C. P., Wilson, M. R., Tapia, P. H., Manzanilla, E. E., Dodson, A. E., Chakraborty, S. et al. (2011). The proteomics of quiescent and nonquiescent cell differentiation in yeast stationaryphase cultures. Mol. Biol. Cell 22, 988-998.

de la Torre-Ruiz, M. A., Pujol, N. and Sundaran, V. (2015). Coping with oxidative stress. The yeast model. Curr. Drug Targets 16, 2-12.

de Nobel, J. G., Klis, F. M., Priem, J., Munnik, T. and van den Ende, H. (1990) The glucanase-soluble mannoproteins limit cell wall porosity in Saccharomyces cerevisiae. Yeast Chichester Engl. 6, 491-499.

De Virgilio, C. (2012). The essence of yeast quiescence. FEMS Microbiol. Rev. 36 , 306-339.

Dhawan, J. and Laxman, S. (2015). Decoding the stem cell quiescence cyclelessons from yeast for regenerative biology. J. Cell Sci. 128, 4467-4474

Drabek, K., Gutiérrez, L., Vermeij, M., Clapes, T., Patel, S. R., Boisset, J.-C., van Haren, J., Pereira, A. L., Liu, Z., Akinci, U. et al. (2012). The microtubule plusend tracking protein CLASP2 is required for hematopoiesis and hematopoietic stem cell maintenance. Cell Rep. 2, 781-788.

Drewinko, B., Yang, L. Y., Barlogie, B. and Trujillo, J. M. (1984). Cultured human tumour cells may be arrested in all stages of the cycle during stationary phase: demonstration of quiescent cells in G1, S and G2 phase. Cell Tissue Kinet 17 453-463.

Elliott, B. and Futcher, B. (1993). Stress resistance of yeast cells is largely independent of cell cycle phase. Yeast Chichester Engl. 9, 33-42.

Enenkel, C. (2018). The paradox of proteasome granules. Curr. Genet. 64, 137-140.

Fabrizio, P. and Longo, V. D. (2003). The chronological life span of Saccharomyces cerevisiae. Aging Cell 2, 73-81.

Fehrmann, S., Paoletti, C., Goulev, Y., Ungureanu, A., Aguilaniu, H. and Charvin, G. (2013). Aging yeast cells undergo a sharp entry into senescence unrelated to the loss of mitochondrial membrane potential. Cell Rep. 5 1589-1599.

Fiore, A. P. Z. P., Ribeiro, P. d. F. and Bruni-Cardoso, A. (2018). Sleeping beauty and the microenvironment enchantment: microenvironmental regulation of the proliferation-quiescence decision in normal tissues and in cancer development. Front. Cell Dev. Biol. 6, 59

Friedman, J. R. and Nunnari, J. (2014). Mitochondrial form and function. Nature 505, 335-343.

Gangloff, S. and Arcangioli, B. (2017). DNA repair and mutations during quiescence in yeast. FEMS Yeast Res. 17, 742.

Gangloff, S., Achaz, G., Francesconi, S., Villain, A., Miled, S., Denis, C. and Arcangioli, B. (2017). Quiescence unveils a novel mutational force in fission yeast. eLife 6,149 .

Gasch, A. P., Spellman, P. T., Kao, C. M., Carmel-Harel, O., Eisen, M. B., Storz G., Botstein, D. and Brown, P. O. (2000). Genomic expression programs in the response of yeast cells to environmental changes. Mol. Biol. Cell 11, 4241-4257.

Goddard, M. R. and Greig, D. (2015). Saccharomyces cerevisiae: a nomadic yeast with no niche? FEMS Yeast Res. 15, 702.

Graef, M. (2018). Lipid droplet-mediated lipid and protein homeostasis in budding yeast. FEBS Lett. 592, 1291-1303.

Gray, J. V., Petsko, G. A., Johnston, G. C., Ringe, D., Singer, R. A. and WernerWashburne, M. (2004). "Sleeping beauty": quiescence in Saccharomyces cerevisiae. Microbiol. Mol. Biol. Rev. MMBR 68, 187-206.

Gu, Z. C., Wu, E., Sailer, C., Jando, J., Styles, E., Eisenkolb, I., Kuschel, M. Bitschar, K., Wang, X., Huang, L. et al. (2017). Ubiquitin orchestrates 
proteasome dynamics between proliferation and quiescence in yeast. Mol. Biol Cell 28, 2479-2491.

Guidi, M., Ruault, M., Marbouty, M., Loïodice, I., Cournac, A., Billaudeau, C., Hocher, A., Mozziconacci, J., Koszul, R. and Taddei, A. (2015). Spatial reorganization of telomeres in long-lived quiescent cells. Genome Biol. 16, 206.

Herman, P. K. (2002). Stationary phase in yeast. Curr. Opin. Microbiol. 5, 602-607.

Hitomi, M. and Stacey, D. W. (1999). Cyclin D1 production in cycling cells depends on ras in a cell-cycle-specific manner. Curr. Biol. 9, 1075-1084.

Hughes, A. L. and Gottschling, D. E. (2012). An early age increase in vacuolar pH limits mitochondrial function and lifespan in yeast. Nature 492, 261-265.

Jensen, P. V. and Larsson, L.-I. (2004). Actin microdomains on endothelial cells: association with CD44, ERM proteins, and signaling molecules during quiescence and wound healing. Histochem. Cell Biol. 121, 361-369.

Jones, K. M., Sarić, N., Russell, J. P., Andoniadou, C. L., Scambler, P. J. and Basson, M. A. (2015). CHD7 maintains neural stem cell quiescence and prevents premature stem cell depletion in the adult hippocampus. Stem Cells Dayt. Ohio 33, 196-210.

Jorgensen, P. and Tyers, M. (2004). How cells coordinate growth and division Curr. Biol. 14, R1014-R1027.

Joyner, R. P., Tang, J. H., Helenius, J., Dultz, E., Brune, C., Holt, L. J., Huet, S. Müller, D. J. and Weis, K. (2016). A glucose-starvation response regulates the diffusion of macromolecules. eLife 5, 833

Kaganovich, D., Kopito, R. and Frydman, J. (2008). Misfolded proteins partition between two distinct quality control compartments. Nature 454, 1088-1095.

Kedersha, N. and Anderson, P. (2002). Stress granules: sites of mRNA triage that regulate mRNA stability and translatability. Biochem. Soc. Trans. 30, 963-969.

Klosinska, M. M., Crutchfield, C. A., Bradley, P. H., Rabinowitz, J. D. and Broach, J. R. (2011). Yeast cells can access distinct quiescent states. Genes Dev. 25, 336-349.

Kyryakov, P., Beach, A., Richard, V. R., Burstein, M. T., Leonov, A., Levy, S. and Titorenko, V. I. (2012). Caloric restriction extends yeast chronological lifespan by altering a pattern of age-related changes in trehalose concentration. Front. Physiol. 3, 256

Laporte, D. and Sagot, I. (2014). Microtubules move the nucleus to quiescence. Nucl. Austin Tex 5, 113-118.

Laporte, D., Salin, B., Daignan-Fornier, B. and Sagot, I. (2008). Reversible cytoplasmic localization of the proteasome in quiescent yeast cells. J. Cell Biol. 181, 737-745.

Laporte, D., Lebaudy, A., Sahin, A., Pinson, B., Ceschin, J., Daignan-Fornier, B and Sagot, I. (2011). Metabolic status rather than cell cycle signals contro quiescence entry and exit. J. Cell Biol. 192, 949-957.

Laporte, D., Courtout, F., Salin, B., Ceschin, J. and Sagot, I. (2013). An array of nuclear microtubules reorganizes the budding yeast nucleus during quiescence. J. Cell Biol. 203, 585-594.

Laporte, D., Courtout, F., Pinson, B., Dompierre, J., Salin, B., Brocard, L. and Sagot, I. (2015). A stable microtubule array drives fission yeast polarity reestablishment upon quiescence exit. J. Cell Biol. 210, 99-113.

Laporte, D., Courtout, F., Tollis, S. and Sagot, I. (2016). Quiescent Saccharomyces cerevisiae forms telomere hyperclusters at the nuclear membrane vicinity through a multifaceted mechanism involving Esc1, the Sir complex, and chromatin condensation. Mol. Biol. Cell 27, 1875-1884.

Laporte, D., Jimenez, L., Gouleme, L. and Sagot, I. (2017). Yeast quiescence exit swiftness is influenced by cell volume and chronological age. Microb. Cell 5, 104-111.

Laporte, D., Gouleme, L., Jimenez, L., Khemiri, I. and Sagot, I. (2018) Mitochondria reorganization upon proliferation arrest predicts individual yeast cell fate. eLife 7, 113

Lemons, J. M. S., Feng, X.-J., Bennett, B. D., Legesse-Miller, A., Johnson, E. L., Raitman, I., Pollina, E. A., Rabitz, H. A., Rabinowitz, J. D. and Coller, H. A (2010). Quiescent fibroblasts exhibit high metabolic activity. PLoS Biol. 8, e1000514.

Li, L., Miles, S., Melville, Z., Prasad, A., Bradley, G. and Breeden, L. L. (2013) Key events during the transition from rapid growth to quiescence in budding yeast require posttranscriptional regulators. Mol. Biol. Cell 24, 3697-3709.

Lillie, S. H. and Pringle, J. R. (1980). Reserve carbohydrate metabolism in Saccharomyces cerevisiae: responses to nutrient limitation. J. Bacteriol. 143, 1384-1394

Liu, I.-C., Chiu, S.-W., Lee, H.-Y. and Leu, J.-Y. (2012). The histone deacetylase Hos2 forms an Hsp42-dependent cytoplasmic granule in quiescent yeast cells. Mol. Biol. Cell 23, 1231-1242.

Marshall, R. S. and Vierstra, R. D. (2018). Proteasome storage granules protect proteasomes from autophagic degradation upon carbon starvation. eLife 7 , e34532.

Marshall, R. S., McLoughlin, F. and Vierstra, R. D. (2016). Autophagic turnover of inactive $26 \mathrm{~S}$ proteasomes in yeast is directed by the ubiquitin receptor cue 5 and the Hsp42 chaperone. Cell Rep. 16, 1717-1732.

Marthandan, S., Priebe, S., Hemmerich, P., Klement, K. and Diekmann, S. (2014). Long-term quiescent fibroblast cells transit into senescence. PLOS ONE 9 e115597.
Martinez, M. J., Roy, S., Archuletta, A. B., Wentzell, P. D., Anna-Arriola, S. S. Rodriguez, A. L., Aragon, A. D., Quiñones, G. A., Allen, C. and WernerWashburne, M. (2004). Genomic analysis of stationary-phase and exit in Saccharomyces cerevisiae: gene expression and identification of novel essential genes. Mol. Biol. Cell 15, 5295-5305.

Matson, J. P. and Cook, J. G. (2017). Cell cycle proliferation decisions: the impact of single cell analyses. FEBS J. 284, 362-375.

McFaline-Figueroa, J. R., Vevea, J., Swayne, T. C., Zhou, C., Liu, C., Leung, G. Boldogh, I. R. and Pon, L. A. (2011). Mitochondrial quality control during inheritance is associated with lifespan and mother-daughter age asymmetry in budding yeast. Aging Cell 10, 885-895.

Miles, S. and Breeden, L. (2016). A common strategy for initiating the transition from proliferation to quiescence. Curr. Genet. 63, 179-186.

Mishra, M., Huang, J. and Balasubramanian, M. K. (2014). The yeast actin cytoskeleton. FEMS Microbiol. Rev. 38, 213-227.

Mohammad, K., Dakik, P., Medkour, Y., McAuley, M., Mitrofanova, D. and Titorenko, V. I. (2018). Some Metabolites act as second messengers in yeast chronological aging. Int. J. Mol. Sci. 19, 860.

Mortimer, R. K. and Johnston, J. R. (1959). Life span of individual yeast cells. Nature 183, 1751-1752.

Munder, M. C., Midtvedt, D., Franzmann, T., Nüske, E., Otto, O., Herbig, M. Ulbricht, E., Müller, P., Taubenberger, A., Maharana, S. et al. (2016). A pH driven transition of the cytoplasm from a fluid- to a solid-like state promotes entry into dormancy. eLife 5, e09347.

Munro, J., Steeghs, K., Morrison, V., Ireland, H. and Parkinson, E. K. (2001) Human fibroblast replicative senescence can occur in the absence of extensive cell division and short telomeres. Oncogene 20, 3541-3552.

Muroyama, A. and Lechler, T. (2017). Microtubule organization, dynamics and functions in differentiated cells. Dev. Camb. Engl. 144, 3012-3021.

Nakamura-Ishizu, A., Takizawa, H. and Suda, T. (2014). The analysis, roles and regulation of quiescence in hematopoietic stem cells. Dev. Camb. Engl. 141, 4656-4666.

Narayanaswamy, R., Levy, M., Tsechansky, M., Stovall, G. M., O’Connell, J. D., Mirrielees, J., Ellington, A. D. and Marcotte, E. M. (2009). Widespread reorganization of metabolic enzymes into reversible assemblies upon nutrient starvation. Proc. Natl. Acad. Sci. USA 106, 10147-10152.

Nemec, A. A., Howell, L. A., Peterson, A. K., Murray, M. A. and Tomko, R. J. (2017). Autophagic clearance of proteasomes in yeast requires the conserved sorting nexin Snx4. J. Biol. Chem. 292, 21466-21480.

Noree, C., Sato, B. K., Broyer, R. M. and Wilhelm, J. E. (2010). Identification of novel filament-forming proteins in Saccharomyces cerevisiae and Drosophila melanogaster. J. Cell Biol. 190, 541-551.

Noree, C., Monfort, E., Shiau, A. K. and Wilhelm, J. E. (2014). Common regulatory control of CTP synthase enzyme activity and filament formation. Mol. Biol. Cell 25 , 2282-2290.

Ocampo, A., Liu, J., Schroeder, E. A., Shadel, G. S. and Barrientos, A. (2012) Mitochondrial respiratory thresholds regulate yeast chronological life span and its extension by caloric restriction. Cell Metab. 16, 55-67.

O’Connell, J. D., Zhao, A., Ellington, A. D. and Marcotte, E. M. (2012). Dynamic reorganization of metabolic enzymes into intracellular bodies. Annu. Rev. Cell Dev. Biol. 28, 89-111.

O’Connell, J. D., Tsechansky, M., Royal, A., Boutz, D. R., Ellington, A. D. and Marcotte, E. M. (2014). A proteomic survey of widespread protein aggregation in yeast. Mol. Biosyst. 10, 851-861.

O'Farrell, P. H. (2011). Quiescence: early evolutionary origins and universality do not imply uniformity. Philos. Trans. R. Soc. Lond. B. Biol. Sci. 366, 3498-3507.

Palková, Z., Wilkinson, D. and Váchová, L. (2014). Aging and differentiation in yeast populations: elders with different properties and functions. FEMS Yeast Res. 14, 96-108.

Parker, R. and Sheth, U. (2007). P bodies and the control of mRNA translation and degradation. Mol. Cell 25, 635-646.

Peters, L. Z., Hazan, R., Breker, M., Schuldiner, M. and Ben-Aroya, S. (2013). Formation and dissociation of proteasome storage granules are regulated by cytosolic pH. J. Cell Biol. 201, 663-671.

Peters, L. Z., Karmon, O., Miodownik, S. and Ben-Aroya, S. (2016). Proteasome storage granules are transiently associated with the insoluble protein deposit in Saccharomyces cerevisiae. J. Cell Sci. 129, 1190-1197.

Petrovska, I., Nüske, E., Munder, M. C., Kulasegaran, G., Malinovska, L., Kroschwald, S., Richter, D., Fahmy, K., Gibson, K., Verbavatz, J.-M. et al. (2014). Filament formation by metabolic enzymes is a specific adaptation to an advanced state of cellular starvation. eLife 3, e02409.

Piñon, R. (1978). Folded chromosomes in non-cycling yeast cells: evidence for a characteristic g0 form. Chromosoma 67, 263-274

Pitaval, A., Senger, F., Letort, G., Gidrol, X., Guyon, L., Sillibourne, J. and Théry, M. (2017). Microtubule stabilization drives 3D centrosome migration to initiate primary ciliogenesis. J. Cell Biol. 216, 3813-3728.

Poulter, N. S., Staiger, C. J., Rappoport, J. Z. and Franklin-Tong, V. E. (2010) Actin-binding proteins implicated in the formation of the punctate actin foci stimulated by the self-incompatibility response in Papaver. Plant Physiol. 152 1274-1283. 
Radonjic, M., Andrau, J.-C., Lijnzaad, P., Kemmeren, P., Kockelkorn, T. T. J. P. van Leenen, D., van Berkum, N. L. and Holstege, F. C. P. (2005). Genome-wide analyses reveal RNA polymerase II located upstream of genes poised for rapid response upon S. cerevisiae stationary phase exit. Mol. Cell 18, 171-183.

Ramachandran, V., Shah, K. H. and Herman, P. K. (2011). The cAMP-dependen protein kinase signaling pathway is a key regulator of $\mathrm{P}$ body foci formation. $\mathrm{Mol}$. Cell 43, 973-981.

Riback, J. A., Katanski, C. D., Kear-Scott, J. L., Pilipenko, E. V., Rojek, A. E., Sosnick, T. R. and Drummond, D. A. (2017). Stress-triggered phase separation is an adaptive, evolutionarily tuned response. Cell 168, 1028-1040.e19.

Rittershaus, E. S. C., Baek, S.-H. and Sassetti, C. M. (2013). The normalcy of dormancy: common themes in microbial quiescence. Cell Host Microbe 13 643-651.

Roche, B., Arcangioli, B. and Martienssen, R. (2017). Transcriptional reprogramming in cellular quiescence. RNA Biol. 14, 843-853.

Rodgers, J. T., King, K. Y., Brett, J. O., Cromie, M. J., Charville, G. W., Maguire, K. K., Brunson, C., Mastey, N., Liu, L., Tsai, C.-R. et al. (2014). mTORC1 controls the adaptive transition of quiescent stem cells from $\mathrm{G} 0$ to $\mathrm{G}$ (Alert). Nature 510, 393-396.

Ruault, M., De Meyer, A., Loïodice, I. and Taddei, A. (2011). Clustering heterochromatin: Sir3 promotes telomere clustering independently of silencing in yeast. J. Cell Biol. 192, 417-431.

Ruiz-Miró, M., Colomina, N., Fernández, R. M. H., Garí, E., Gallego, C. and Aldea, M. (2011). Translokin (Cep57) interacts with cyclin D1 and prevents its nuclear accumulation in quiescent fibroblasts. Traffic 12, 549-562.

Rumman, M., Dhawan, J. and Kassem, M. (2015). Concise review: quiescence in adult stem cells: biological significance and relevance to tissue regeneration. Stem Cells Dayt. Ohio 33, 2903-2912.

Rutledge, M. T., Russo, M., Belton, J.-M., Dekker, J. and Broach, J. R. (2015) The yeast genome undergoes significant topological reorganization in quiescence. Nucleic Acids Res. 43, 8299-8313.

Sagot, I., Pinson, B., Salin, B. and Daignan-Fornier, B. (2006). Actin bodies in yeast quiescent cells: an immediately available actin reserve? Mol. Biol. Cell 17 4645-4655.

Samokhvalov, V., Ignatov, V. and Kondrashova, M. (2004). Reserve carbohydrates maintain the viability of Saccharomyces cerevisiae cells during chronological aging. Mech. Ageing Dev. 125, 229-235.

Sampaio-Marques, B., Burhans, W. C. and Ludovico, P. (2014). Longevity pathways and maintenance of the proteome: the role of autophagy and mitophagy during yeast ageing. Microb. Cell Graz Austria 1, 118-127.

Sandager, L., Gustavsson, M. H., Ståhl, U., Dahlqvist, A., Wiberg, E., Banas, A., Lenman, M., Ronne, H. and Stymne, S. (2002). Storage lipid synthesis is nonessential in yeast. J. Biol. Chem. 277, 6478-6482.

Saunier, R., Esposito, M., Dassa, E. P. and Delahodde, A. (2013). Integrity of the Saccharomyces cerevisiae Rpn11 protein is critical for formation of proteasome storage granules (PSG) and survival in stationary phase. PLoS ONE 8, e70357.

Scheckhuber, C. Q., Erjavec, N., Tinazli, A., Hamann, A., Nyström, T. and Osiewacz, H. D. (2007). Reducing mitochondrial fission results in increased life span and fitness of two fungal ageing models. Nat. Cell Biol. 9, 99-105.

Sfakianos, A. P., Whitmarsh, A. J. and Ashe, M. P. (2016). Ribonucleoprotein bodies are phased in. Biochem. Soc. Trans. 44, 1411-1416.

Shah, K. H., Zhang, B., Ramachandran, V. and Herman, P. K. (2013). Processing body and stress granule assembly occur by independent and differentially regulated pathways in Saccharomyces cerevisiae. Genetics 193, 109-123.

Shah, K. H., Nostramo, R., Zhang, B., Varia, S. N., Klett, B. M. and Herman, P. K (2014). Protein kinases are associated with multiple, distinct cytoplasmic granules in quiescent yeast cells. Genetics 198, 1495-1512.

Sheth, U. and Parker, R. (2003). Decapping and decay of messenger RNA occur in cytoplasmic processing bodies. Science 300, 805-808.

Shi, L., Sutter, B. M., Ye, X. and Tu, B. P. (2010). Trehalose is a key determinant of the quiescent metabolic state that fuels cell cycle progression upon return to growth. Mol. Biol. Cell 21, 1982-1990.

Silva, V. C. and Cassimeris, L. (2013). Stathmin and microtubules regulate mitotic entry in HeLa cells by controlling activation of both Aurora kinase A and PIk1. Mol. Biol. Cell 24, 3819-3831.

Singh, P. and Li, R. (2017). Emerging roles for sphingolipids in cellular aging. Curr Genet. 64, 761-767.

Soprano, K. J. (1994). WI-38 cell long-term quiescence model system: a valuable tool to study molecular events that regulate growth. J. Cell. Biochem. 54, 405-414.

Spencer, S. L., Cappell, S. D., Tsai, F.-C., Overton, K. W., Wang, C. L. and Meyer, T. (2013). The proliferation-quiescence decision is controlled by a bifurcation in CDK2 activity at mitotic exit. Cell 155, 369-383.

Spokoini, R., Moldavski, O., Nahmias, Y., England, J. L., Schuldiner, M. and Kaganovich, D. (2012). Confinement to organelle-associated inclusion structures mediates asymmetric inheritance of aggregated protein in budding yeast. Cell Rep. 2, 738-747.
Su, S. S., Tanaka, Y., Samejima, I., Tanaka, K. and Yanagida, M. (1996). A nitrogen starvation-induced dormant G0 state in fission yeast: the establishment from uncommitted G1 state and its delay for return to proliferation. J. Cell Sci. 109 1347-1357.

Sun, D. and Buttitta, L. (2017). States of G0 and the proliferation-quiescence decision in cells, tissues and during development. Int. J. Dev. Biol. 61, 357-366.

Sutcu, H. H. and Ricchetti, M. (2018). Loss of heterogeneity, quiescence, and differentiation in muscle stem cells. Stem Cell Investig. 5, 9.

Svenkrtova, A., Belicova, L., Volejnikova, A., Sigler, K., Jazwinski, S. M. and Pichova, A. (2016). Stratification of yeast cells during chronological aging by size points to the role of trehalose in cell vitality. Biogerontology 17, 395-408.

Taddei, A., Schober, H. and Gasser, S. M. (2010). The budding yeast nucleus Cold Spring Harb. Perspect. Biol. 2, a000612.

Takeo, K., Tanaka, R., Miyaji, M. and Nishimura, K. (1995). Unbudded G2 as well as $\mathrm{G} 1$ arrest in the stationary phase of the basidiomycetous yeast Cryptococcus neoformans. FEMS Microbiol. Lett. 129, 231-235

Tapia, H. and Morano, K. A. (2010). Hsp90 nuclear accumulation in quiescence is linked to chaperone function and spore development in yeast. Mol. Biol. Cell 21 63-72.

Teixeira, D., Sheth, U., Valencia-Sanchez, M. A., Brengues, M. and Parker, R. (2005). Processing bodies require RNA for assembly and contain nontranslating mRNAs. RNA 11, 371-382.

Terzi, M. Y., Izmirli, M. and Gogebakan, B. (2016). The cell fate: senescence or quiescence. Mol. Biol. Rep. 43, 1213-1220

Tierney, M. T. and Sacco, A. (2016). Satellite cell heterogeneity in skeletal muscle homeostasis. Trends Cell Biol. 26, 434-444.

Trancíková, A., Weisová, P., Kissová, I., Zeman, I. and Kolarov, J. (2004) Production of reactive oxygen species and loss of viability in yeast mitochondrial mutants: protective effect of Bcl-xL. FEMS Yeast Res. 5, 149-156.

Valcourt, J. R., Lemons, J. M. S., Haley, E. M., Kojima, M., Demuren, O. O. and Coller, H. A. (2012). Staying alive: metabolic adaptations to quiescence. Cell Cycle Georget. Tex 11, 1680-1696.

van Deventer, S., Menendez-Benito, V., van Leeuwen, F. and Neefjes, J. (2015) $\mathrm{N}$-terminal acetylation and replicative age affect proteasome localization and cell fitness during aging. J. Cell Sci. 128, 109-117.

van Velthoven, C. T. J., de Morree, A., Egner, I. M., Brett, J. O. and Rando, T. A (2017). Transcriptional profiling of quiescent muscle stem cells in vivo. Cell Rep. 21, 1994-2004

Veatch, J. R., McMurray, M. A., Nelson, Z. W. and Gottschling, D. E. (2009) Mitochondrial dysfunction leads to nuclear genome instability via an iron-sulfur cluster defect. Cell 137, 1247-1258.

Velappan, Y., Signorelli, S. and Considine, M. J. (2017). Cell cycle arrest in plants: what distinguishes quiescence, dormancy and differentiated G1? Ann. Bot 120 495-509.

Waite, K. A., De-La Mota-Peynado, A., Vontz, G. and Roelofs, J. (2016) Starvation induces proteasome autophagy with different pathways for core and regulatory particles. J. Biol. Chem. 291, 3239-3253.

Weberruss, M. H., Savulescu, A. F., Jando, J., Bissinger, T., Harel, A., Glickman, M. H. and Enenkel, C. (2013). BIm10 facilitates nuclear import of proteasome core particles. EMBO J. 32, 2697-2707.

Werner-Washburne, M., Roy, S. and Davidson, G. S. (2012). Aging and the survival of quiescent and non-quiescent cells in yeast stationary-phase cultures. Subcell. Biochem. 57, 123-143.

Wilkins, K. A., Bosch, M., Haque, T., Teng, N., Poulter, N. S. and Franklin-Tong, V. E. (2015). Self-incompatibility-induced programmed cell death in field poppy pollen involves dramatic acidification of the incompatible pollen tube cytosol. Plant Physiol. 167, 766-779

Winey, M. and Bloom, K. (2012). Mitotic spindle form and function. Genetics 190 1197-1224.

Yamasaki, S. and Anderson, P. (2008). Reprogramming mRNA translation during stress. Curr. Opin. Cell Biol. 20, 222-226.

Yang, J., Tanaka, Y., Seay, M., Li, Z., Jin, J., Garmire, L. X., Zhu, X., Taylor, A., Li, W., Euskirchen, G. et al. (2017). Single cell transcriptomics reveals unanticipated features of early hematopoietic precursors. Nucleic Acids Res. 45, 1281-1296.

Yoon, Y.-S., Yoon, D.-S., Lim, I. K., Yoon, S.-H., Chung, H.-Y., Rojo, M., Malka, F., Jou, M.-J., Martinou, J.-C. and Yoon, G. (2006). Formation of elongated giant mitochondria in DFO-induced cellular senescence: involvement of enhanced fusion process through modulation of Fis1. J. Cell. Physiol. 209, 468-480.

Zaman, S., Lippman, S. I., Zhao, X. and Broach, J. R. (2008). How Saccharomyces responds to nutrients. Annu. Rev. Genet. 42, 27-81.

Zhang, X., Cai, J., Zheng, Z., Polin, L., Lin, Z., Dandekar, A., Li, L., Sun, F., Finley, R. L., Fang, D. et al. (2015). A novel ER-microtubule-binding protein ERLIN2, stabilizes Cyclin B1 and regulates cell cycle progression. Cell Discov. 1 15024

Zottini, M., Barizza, E., Bastianelli, F., Carimi, F. and Lo Schiavo, F. (2006) Growth and senescence of Medicago truncatula cultured cells are associated with characteristic mitochondrial morphology. New Phytol. 172, 239-247. 
Table S1. Protein re-localization in non proliferating cells (in WT and mutants)

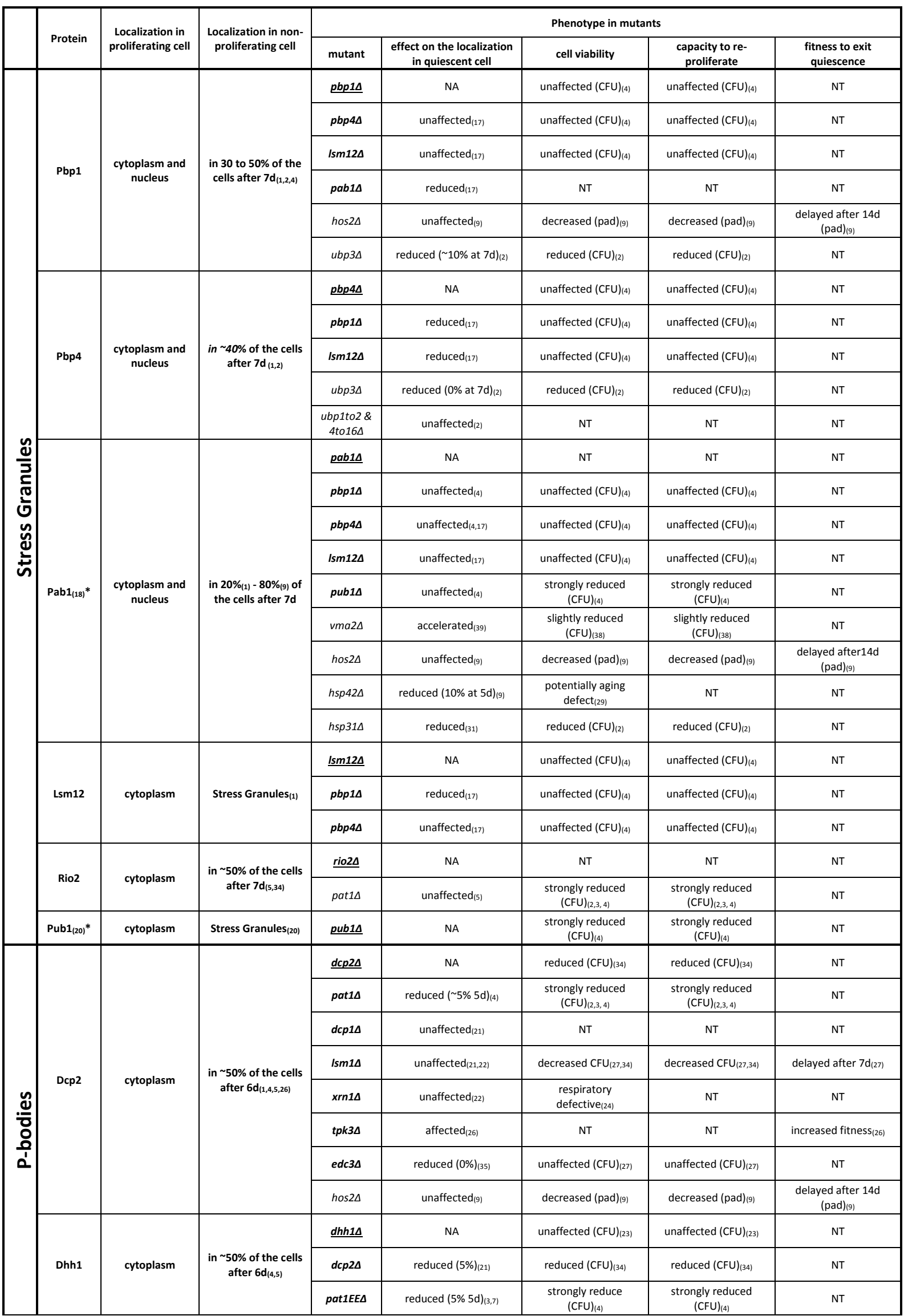




\begin{tabular}{|c|c|c|c|c|c|c|c|c|}
\hline & & & & $d c p 1 \Delta$ & unaffected $(7,21)$ & NT & NT & NT \\
\hline & & & & xrm1s & increased $_{(7,21)}$ & $\begin{array}{l}\text { respiratory defective } \\
\text { (24) }\end{array}$ & NT & NT \\
\hline & & & & edc3s & reduced $(0 \%)_{(35)}$ & unaffected (CFU) $(27)$ & unaffected (CFU)(27) & NT \\
\hline & & & & $p b p 1 \Delta$ & unaffected $_{(17)}$ & unaffected (CFU) & unaffected (CFU) $)_{(4)}$ & NT \\
\hline & & & & $p b p 4 \Delta$ & unaffected $_{(17)}$ & unaffected (CFU) & unaffected (CFU) $)_{(4)}$ & NT \\
\hline & & & & $\mid s m 12 \Delta$ & unaffected $_{(17,21)}$ & unaffected (CFU)(4) & unaffected (CFU) $)_{(4)}$ & NT \\
\hline & \multirow{9}{*}{ Edc3 } & \multirow{9}{*}{ cytoplasm } & \multirow{9}{*}{$\begin{array}{l}\text { in } 35 \% \text { of the cells } \\
\text { after } 5 d_{(1,2,4,9)}\end{array}$} & $\underline{\operatorname{edc} 3 \Delta}$ & NA & unaffected (CFU) & unaffected (CFU) (27) & NT \\
\hline & & & & pat1s & reduced $(\sim 10 \% 5 \mathrm{~d})_{(4)}$ & $\begin{array}{l}\text { strongly reduce } \\
\text { (CFU) })_{(2-4)}\end{array}$ & $\begin{array}{l}\text { strongly reduce } \\
\text { (CFU) })_{(2-4)}\end{array}$ & NT \\
\hline & & & & $d c p 1 \Delta$ & unaffected $_{(21)}$ & NT & NT & NT \\
\hline & & & & $\operatorname{lsm} 12 \Delta$ & unaffected $_{(17,21)}$ & unaffected (CFU) & unaffected (CFU) & NT \\
\hline & & & & $v m a 2 \Delta$ & $\operatorname{accelerated}_{(39)}$ & $\begin{array}{l}\text { slightly reduced } \\
(\text { CFU })_{(38)}\end{array}$ & $\begin{array}{l}\text { slightly reduced } \\
(\mathrm{CFU})_{(38)}\end{array}$ & NT \\
\hline & & & & $p b p 4 \Delta$ & unaffected $\mathrm{d}_{(4,17)}$ & unaffected (CFU) $)_{(4)}$ & unaffected (CFU) $)_{(4)}$ & NT \\
\hline & & & & pbp1 $1 \Delta$ & unaffected $_{(4)}$ & unaffected (CFU) $)_{(4)}$ & unaffected (CFU) $)_{(4)}$ & NT \\
\hline & & & & pub1s & reduced $(1 \% 5 \mathrm{~d})_{(4)}$ & $\begin{array}{l}\text { strongly reduced } \\
(\mathrm{CFU})_{(4)}\end{array}$ & $\begin{array}{l}\text { strongly reduced } \\
\text { (CFU) })_{(4)}\end{array}$ & NT \\
\hline & & & & ubp3 $\Delta$ & unaffected $_{(2)}$ & reduced $(\mathrm{CFU})_{(2)}$ & reduced $(\mathrm{CFU})_{(2)}$ & NT \\
\hline & \multirow{5}{*}{ Pat1 } & \multirow{5}{*}{ cytoplasm } & \multirow{5}{*}{$\begin{array}{l}\text { in }>40 \% \text { of the cells } \\
\text { after } 5 d_{(4,5)}\end{array}$} & pat1s & NA & $\begin{array}{l}\text { strongly reduced } \\
(\text { CFU })_{(2,3,4)}\end{array}$ & $\begin{array}{l}\text { strongly reduced } \\
\text { (CFU) }(2,3,4)\end{array}$ & NT \\
\hline & & & & pat1EE & reduced $(6 \% 5 d)_{(4)}$ & $\begin{array}{l}\text { strongly reduced } \\
(\mathrm{CFU})_{(4)}\end{array}$ & $\begin{array}{l}\text { strongly reduced } \\
(\mathrm{CFU})_{(4)}\end{array}$ & NT \\
\hline & & & & $\underline{e d c 3 \Delta}$ & reduced $(0 \%)_{(35)}$ & unaffected (CFU) & unaffected (CFU) & NT \\
\hline & & & & $d c p 2 \Delta$ & reduced $(5 \%)_{(21)}$ & reduced $(\mathrm{CFU})_{(34)}$ & reduced $(\mathrm{CFU})_{(34)}$ & NT \\
\hline & & & & $d c p 1 \Delta$ & unaffected $_{(21)}$ & NT & NT & NT \\
\hline & \multirow{5}{*}{ Dep1 } & \multirow{5}{*}{ cytoplasm } & \multirow{5}{*}{$\begin{array}{l}\text { in } \sim 40 \% \text { of the cells } \\
\text { after } 6 d_{(25)}\end{array}$} & $\underline{d c p 1 \Delta}$ & NA & NT & NT & NT \\
\hline & & & & $d c p 2 \Delta$ & reduced $_{(21)}$ & reduced $(\mathrm{CFU})_{(34)}$ & reduced $(\mathrm{CFU})_{(34)}$ & NT \\
\hline & & & & 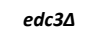 & reduced $(0 \%)_{(35)}$ & unaffected (CFU) & unaffected (CFU) (27) & NT \\
\hline & & & & $x r n 1 \Delta$ & reduced $_{(21)}$ & $\begin{array}{l}\text { respiratory } \\
\text { defective }_{(24)}\end{array}$ & NT & NT \\
\hline & & & & hsp314 & reduced $_{(31)}$ & reduced (CFU) $)_{(31)}$ & reduced $(\mathrm{CFU})_{(31)}$ & NT \\
\hline & \multirow{2}{*}{ Hrr25 } & \multirow{2}{*}{ nucleus } & \multirow{2}{*}{$\begin{array}{l}\text { in } 55 \% \text { of the cells } \\
\text { after } 7 d_{(5)}\end{array}$} & 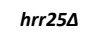 & NT & NT & NT & NT \\
\hline & & & & $d c p 2 \Delta$ & reduced $_{(6)}$ & reduced $(\mathrm{CFU})_{(34)}$ & reduced $(\mathrm{CFU})_{(34)}$ & NT \\
\hline & \multirow{3}{*}{ Xrn1 } & \multirow{3}{*}{ cytoplasm } & \multirow{3}{*}{$\begin{array}{l}\text { in }>\mathbf{5 0 \%} \text { of the } \\
\text { cells }\end{array}$} & $\underline{x r m 1 \Delta}$ & NA & $\begin{array}{l}\text { respiratory } \\
\text { defective }_{(24)}\end{array}$ & NT & NT \\
\hline & & & & 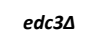 & reduced $(0 \%)_{(35)}$ & unaffected (CFU) (27) & unaffected (CFU) & NT \\
\hline & & & & Ism12 & unaffected $_{(21)}$ & unaffected (CFU) $)_{(4)}$ & unaffected (CFU) $)_{(4)}$ & NT \\
\hline & \multirow{4}{*}{ Lsm1-7 } & \multirow{4}{*}{ cytoplasm } & \multirow{4}{*}{$\begin{array}{l}\text { in }>50 \% \text { of the } \\
\text { cells } s_{(7,22)}\end{array}$} & Ism1 & NA & decreased $\mathrm{CFU}_{(27,34)}$ & decreased $\mathrm{CFU}_{(27,34)}$ & delayed at $7 d_{(27)}$ \\
\hline & & & & pat1s & reduced $_{(21)}$ & $\begin{array}{l}\text { strongly reduced } \\
\text { (CFU) }(2,3,4)\end{array}$ & $\begin{array}{l}\text { strongly reduced } \\
\text { (CFU) }(2,3,4)\end{array}$ & NT \\
\hline & & & & edc3s & reduced $(0 \%)_{(35)}$ & unaffected (CFU) $(27)$ & unaffected (CFU) & NT \\
\hline & & & & $d c p 2 \Delta$ & reduced(22) $_{(2)}$ & reduced (CFU)(34) & reduced $(\mathrm{CFU})_{(34)}$ & NT \\
\hline & Cdc28 & cytoplasm & $\begin{array}{c}\text { in } \sim 40 \% \text { of the cells } \\
\text { after } 7 d_{(5)}\end{array}$ & $\underline{c d c 28 \Delta^{* *}}$ & NA & NT & NT & NT \\
\hline & Tpk2/3* & $\begin{array}{c}\text { cytoplasm and } \\
\text { nucleus }\end{array}$ & $\begin{array}{l}\text { in } 30-50 \% \text { of the } \\
\text { cells after } 7 \mathrm{~d}_{(5,25,26)}\end{array}$ & tpk34 & NT & NT & NT & increased fitness(26) \\
\hline & Ypk3 & $\begin{array}{c}\text { diffuse } \\
\text { cytoplasmic }\end{array}$ & $\begin{array}{c}\sim 40 \% \text { cells with PB } \\
\text { at } 7 \mathrm{~d}_{(5)}\end{array}$ & $y p k 3 \Delta$ & NT & NT & NT & NT \\
\hline \multirow{4}{*}{ 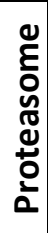 } & \multirow{4}{*}{ Pre10 } & \multirow{4}{*}{ Nuclear } & \multirow{4}{*}{$\begin{array}{c}\text { in }>70 \% \text { of the cells } \\
\text { after } 7 d_{(11,28)}\end{array}$} & blm10s & vacuole $_{(11)}$ & $\begin{array}{l}\text { slightly affected } \\
\text { (CFU) }\end{array}$ & $\begin{array}{c}\text { slightly affected (CFU) } \\
(11,14)\end{array}$ & delayed $_{(11,14)}$ \\
\hline & & & & rpn11-m1 & unaffected $_{(11)}$ & reduced $(\mathrm{CFU})_{(16)}$ & reduce $(\mathrm{CFU})_{(16)}$ & NT \\
\hline & & & & rpn11-m5 & unaffected $_{(11)}$ & unaffected (CFU) $)_{(16)}$ & unaffected $(\mathrm{CFU})_{(16)}$ & NT \\
\hline & & & & hsp $42 \Delta$ & unaffected $(11)$ & $\begin{array}{c}\text { potential aging } \\
\text { defect(29) }^{2}\end{array}$ & NT & NT \\
\hline
\end{tabular}




\begin{tabular}{|c|c|c|c|c|c|c|c|}
\hline & & & ubp3s & unaffected $_{(11)}$ & unaffected $_{(11)}$ & NT & NT \\
\hline & & & nat3D & vacuole $_{(11)}$ & $\begin{array}{l}\text { slightly affected } \\
(\text { CFU) }(11)\end{array}$ & $\begin{array}{l}\text { slightly affected } \\
(\text { CFU) }\end{array}$ & delayed $_{(11)}$ \\
\hline & & & spg $5 \Delta$ & unaffected $_{(11)}$ & affected $(\mathrm{CFU})_{(11)}$ & affected $(\mathrm{CFU})_{(11)}$ & delayed $_{(11)}$ \\
\hline & & & $\underline{r p n 5 \Delta * *}$ & NA & NT & NT & NT \\
\hline \multirow{11}{*}{ Rpn5 } & \multirow{11}{*}{ Nuclear } & \multirow{11}{*}{$\begin{array}{c}\text { in }>70 \% \text { of the cells } \\
\text { after } 7 d_{(11,28)}\end{array}$} & rpn11-m1 & nuclear $_{(16)}$ vacuole $_{(11)}$ & reduced $(\mathrm{CFU})_{(16)}$ & reduced $(\mathrm{CFU})_{(16)}$ & NT \\
\hline & & & rpn11-m5 & vacuole $_{(11)}$ & unaffected (CFU) & unaffected (CFU) & NT \\
\hline & & & blm10s & unaffected $_{(11)}$ & $\begin{array}{l}\text { slightly affected } \\
\text { (CFU) }_{(11,14)}\end{array}$ & $\begin{array}{l}\text { slightly affected } \\
\text { (CFU) }_{(11,14)}\end{array}$ & delayed $_{(11,14)}$ \\
\hline & & & rpn10s & unaffected $_{(16)}$ & unaffected (CFU) & unaffected (CFU) & NT \\
\hline & & & $v m a 2 \Delta$ & accelerated $_{(15)}$ & $\begin{array}{l}\text { slightly reduced } \\
(\text { CFU })_{(38)}\end{array}$ & $\begin{array}{l}\text { slightly reduced } \\
(\text { CFU })_{(38)}\end{array}$ & NT \\
\hline & & & pma1-007 & $\operatorname{accelerated}_{(15)}$ & NT & NT & NT \\
\hline & & & ubp3 $\Delta$ & unaffected $_{(11)}$ & unaffected (CFU) $)_{(11)}$ & unaffected (CFU) $)_{(11)}$ & NT \\
\hline & & & nat $3 \Delta$ & vacuole $_{(11)}$ & $\begin{array}{l}\text { slightly affected } \\
(\text { CFU) }\end{array}$ & $\begin{array}{l}\text { slightly affected } \\
\text { (CFU) }\end{array}$ & delayed $_{(11)}$ \\
\hline & & & ump1s & unaffected $_{(16)}$ & $\begin{array}{c}\text { unaffected }_{(36)} \text { - }^{-} \\
\text {increased cell death }\end{array}$ & unaffected (CFU) $(36)$ & NT \\
\hline & & & spg $5 \Delta$ & unaffected ${ }_{(16)}$-vacuole $(11)$ & affected (CFU)(11) & affected (CFU)(11) & delayed $_{(11)}$ \\
\hline & & & pre5 $5 * *$ & NA & NT & NT & NT \\
\hline \multirow{5}{*}{ Pre5 } & \multirow{5}{*}{ Nuclear } & \multirow{5}{*}{ PSG $_{(12,28)}$} & blm10D & nuclear $_{(14)}$ & $\begin{array}{l}\text { slightly affected } \\
\text { (CFU) }_{(11,14)}\end{array}$ & $\begin{array}{l}\text { slightly affected } \\
\text { (CFU) })_{(11,14)}\end{array}$ & delayed $_{(11,14)}$ \\
\hline & & & $\operatorname{ard} 1 \Delta$ & unaffected $_{(12)}$ & slightly reduce $(\mathrm{CFU})_{(12)}$ & slightly reduce (CFU) $(12)$ & NT \\
\hline & & & nat $3 \Delta$ & cytoplasm $_{(12)}$ & $\begin{array}{l}\text { slightly affected } \\
\text { (CFU) })_{(11,12)}\end{array}$ & $\begin{array}{l}\text { slightly affected } \\
\text { (CFU) })_{(11,12)}\end{array}$ & delayed $_{(11,12)}$ \\
\hline & & & mak3s & $\begin{array}{c}\text { increased nuclear } \\
\text { localization }_{(12)}\end{array}$ & unaffected (CFU)(12) & unaffected (CFU) & NT \\
\hline & & & $\underline{u b i 4 \Delta}$ & NA & reduced $(\mathrm{CFU})_{(19)}$ & reduced $(\mathrm{CFU})_{(19)}$ & delayed $_{(13)}$ \\
\hline Ubi4 & Nuclear & $\mathrm{PSG}_{(13)}$ & ubp64 & NA & NT & NT & delayed $_{(13)}$ \\
\hline Ubp6 & Nuclear & $\mathrm{PSG}_{(13)}$ & pre2 $\Delta^{* *}$ & NA & NT & NT & NT \\
\hline \multirow{6}{*}{ Pre2 } & \multirow{6}{*}{ Nuclear } & \multirow{6}{*}{$\begin{array}{c}\text { in }>90 \% \text { of the cells } \\
\text { after } 7 d_{(13,28)}\end{array}$} & $u b i 4 \Delta$ & nuclear $_{(13)}$ & reduce $(\mathrm{CFU})_{(19)}$ & reduce $(\mathrm{CFU})_{(19)}$ & delayed $_{(13)}$ \\
\hline & & & ubp6s & nuclear $_{(13)}$ & NT & NT & delayed $_{(13)}$ \\
\hline & & & snf1 & affected $_{(13)}$ & NT & NT & NT \\
\hline & & & $n p r 3 \Delta$ & $\operatorname{affected}_{(13)}$ & NT & NT & NT \\
\hline & & & pak1s & $\operatorname{affected}_{(13)}$ & NT & NT & NT \\
\hline & & & rpn1** & NT & NT & NT & NT \\
\hline \multirow{9}{*}{ Rpn1 } & \multirow{9}{*}{ Nuclear } & \multirow{9}{*}{$\begin{array}{c}\text { in }>90 \% \text { of the cells } \\
\text { after } 7 d_{(13,28)}\end{array}$} & ubp6s & nuclear $_{(13)}$ & NT & NT & delayed $_{(13)}$ \\
\hline & & & rpn11-m1 & nuclear $_{(16)}$ & reduced $(\mathrm{CFU})_{(16)}$ & reduced $(\mathrm{CFU})_{(16)}$ & NT \\
\hline & & & rpn11-m5 & unaffected $_{(16)}$ & unaffected (CFU) $)_{(16)}$ & unaffected (CFU) $)_{(16)}$ & NT \\
\hline & & & ubi4s & affected $_{(13)}$ & reduced $(\mathrm{CFU})_{(19)}$ & reduced $(\mathrm{CFU})_{(19)}$ & delayed $_{(13)}$ \\
\hline & & & blm10L & unaffected $_{(14)}$ & $\begin{array}{l}\text { slightly affected } \\
\text { (CFU) }(11,14)\end{array}$ & $\begin{array}{l}\text { slightly affected } \\
\text { (CFU) })_{(11,14)}\end{array}$ & delayed $_{(11,14)}$ \\
\hline & & & 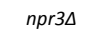 & affected $_{(13)}$ & NT & NT & NT \\
\hline & & & pak1 & $\operatorname{affected}_{(13)}$ & NT & NT & NT \\
\hline & & & snf1 $1 \Delta$ & $\operatorname{affected}_{(13)}$ & NT & NT & NT \\
\hline & & & pre6** & NA & NT & NT & NT \\
\hline \multirow{4}{*}{ Pre6 } & \multirow{4}{*}{ Nuclear } & \multirow{4}{*}{$\begin{array}{c}\text { in >90\% of the cells } \\
\text { after } 7 d_{(13,28)}\end{array}$} & rpn11-m1 & nuclear $_{(16)}$ & reduced $(\mathrm{CFU})_{(16)}$ & reduced $(\mathrm{CFU})_{(16)}$ & NT \\
\hline & & & rpn11-m5 & unaffected $_{(16)}$ & unaffected (CFU) $)_{(16)}$ & unaffected (CFU) $)_{(16)}$ & NT \\
\hline & & & blm10 & nuclear $_{(14)}$ & $\begin{array}{l}\text { slightly affected } \\
\quad(\text { CFU })_{(11,14)}\end{array}$ & $\begin{array}{l}\text { slightly affected } \\
\text { (CFU) })_{(11,14)}\end{array}$ & delayed $_{(11,14)}$ \\
\hline & & & $\underline{b l m 10 \Delta}$ & & $\begin{array}{l}\text { slightly affected } \\
\text { (CFU) })_{(11,14)}\end{array}$ & $\begin{array}{l}\text { slightly affected } \\
\text { (CFU) })_{(11,14)}\end{array}$ & delayed $_{(11,14)}$ \\
\hline
\end{tabular}




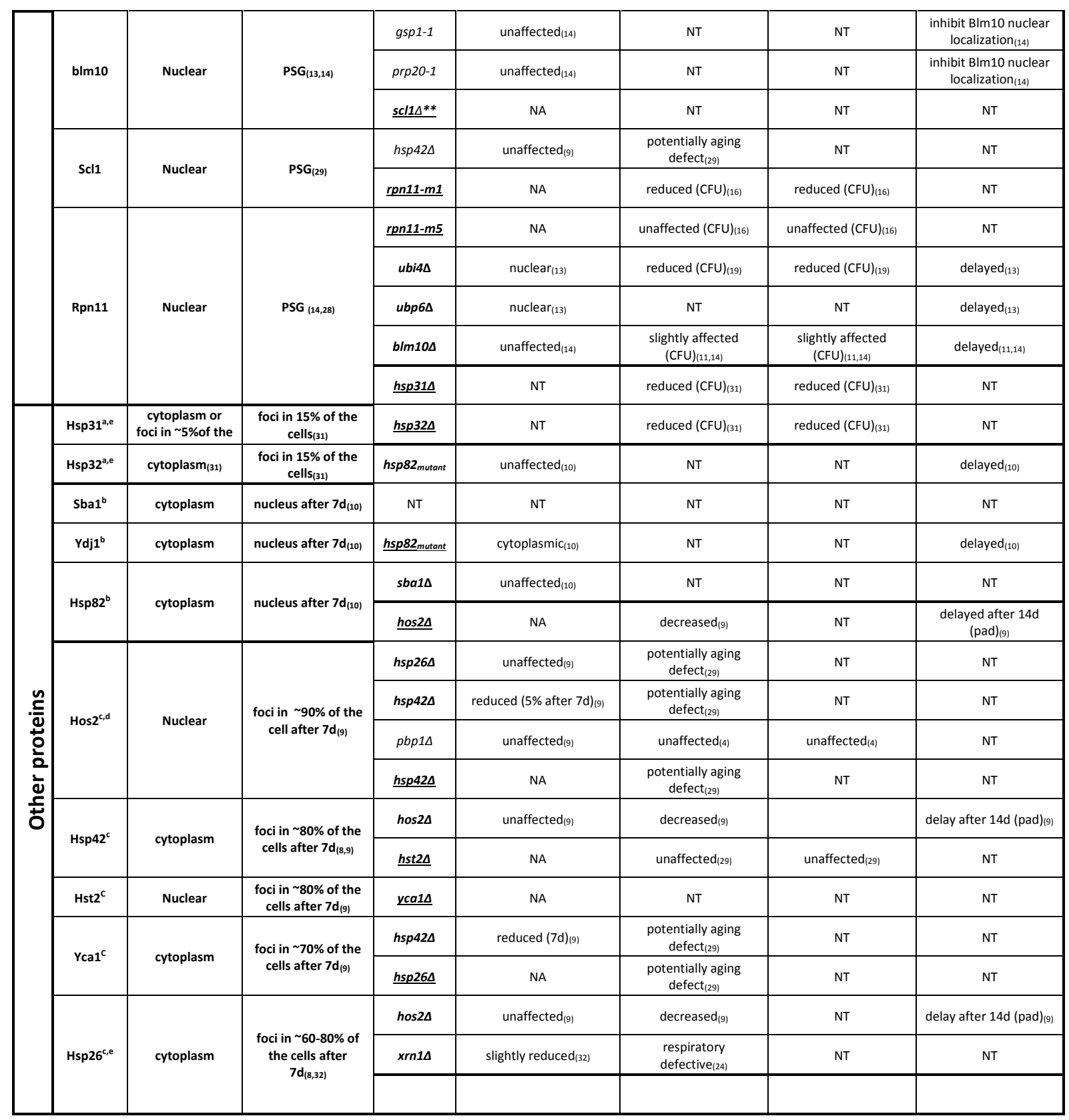

\section{Footnotes}

\section{${ }^{*}$ co-localize with P-bodies}

${ }^{* *}$ essential gene

a - c, co-localize

d, partially co-localize with stress granules(9)

e, partially co-localize with Stress Granules and P-bodies(32,33)

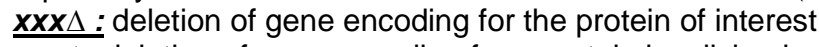

$\boldsymbol{x} \boldsymbol{x} \boldsymbol{x} \Delta$ : deletion of gene encoding for a protein localizing in the structure of interest

$x x x \Delta$ : deletion of gene encoding for a protein unrelated to the structure of interest

NT: not tested

NA: non applicable 


\section{References}

1 - Shah, K. H., Varia, S. N., Cook, L. A. and Herman, P. K. (2016). A Hybrid-Body Containing Constituents of Both P-Bodies and Stress Granules Forms in Response to Hypoosmotic Stress in Saccharomyces cerevisiae. PloS One 11, e0158776.

2 - Nostramo, R., Varia, S. N., Zhang, B., Emerson, M. M. and Herman, P. K. (2016). The Catalytic Activity of the Ubp3 Deubiquitinating Protease Is Required for Efficient Stress Granule Assembly in Saccharomyces cerevisiae. Mol. Cell. Biol. 36, 173-183.

3 - Ramachandran, V., Shah, K. H. and Herman, P. K. (2011). The cAMP-dependent protein kinase signaling pathway is a key regulator of $P$ body foci formation. Mol. Cell 43, 973-981.

4 - Shah, K. H., Zhang, B., Ramachandran, V. and Herman, P. K. (2013). Processing body and stress granule assembly occur by independent and differentially regulated pathways in Saccharomyces cerevisiae. Genetics 193, 109-123.

5 - Shah, K. H., Nostramo, R., Zhang, B., Varia, S. N., Klett, B. M. and Herman, P. K. (2014). Protein kinases are associated with multiple, distinct cytoplasmic granules in quiescent yeast cells. Genetics 198, 1495-1512.

6 - Zhang, B., Shi, Q., Varia, S. N., Xing, S., Klett, B. M., Cook, L. A. and Herman, P. K. (2016). The Activity-Dependent Regulation of Protein Kinase Stability by the Localization to P-Bodies. Genetics 203, 1191-1202.

7- Sheth, U. and Parker, R. (2003). Decapping and decay of messenger RNA occur in cytoplasmic processing bodies. Science $300,805-808$.

8 - Lee, H.-Y., Cheng, K.-Y., Chao, J.-C. and Leu, J.-Y. (2016). Differentiated cytoplasmic granule formation in quiescent and non-quiescent cells upon chronological aging. Microb. Cell Graz Austria 3, 109-119.

9 - Liu, I.-C., Chiu, S.-W., Lee, H.-Y. and Leu, J.-Y. (2012). The histone deacetylase Hos2 forms an Hsp42-dependent cytoplasmic granule in quiescent yeast cells. Mol. Biol. Cell 23, 1231-1242.

10 - Tapia, H. and Morano, K. A. (2010). Hsp90 nuclear accumulation in quiescence is linked to chaperone function and spore development in yeast. Mol. Biol. Cell 21, 63-72.

11 - Marshall, R. S. and Vierstra, R. D. (2018). Proteasome storage granules protect proteasomes from autophagic degradation upon carbon starvation. eLife 7.

12 - van Deventer, S., Menendez-Benito, V., van Leeuwen, F. and Neefjes, J. (2015). N-terminal acetylation and replicative age affect proteasome localization and cell fitness during aging. J. Cell Sci. 128, 109-117.

13 - Gu, Z. C., Wu, E., Sailer, C., Jando, J., Styles, E., Eisenkolb, I., Kuschel, M., Bitschar, K., Wang, X., Huang, L., et al. (2017). Ubiquitin orchestrates proteasome dynamics between proliferation and quiescence in yeast. Mol. Biol. Cell 28, 2479-2491.

14 - Weberruss, M. H., Savulescu, A. F., Jando, J., Bissinger, T., Harel, A., Glickman, M. H. and Enenkel, C. (2013). BIm10 facilitates nuclear import of proteasome core particles. EMBO J. 32, 2697-2707.

15 - Peters, L. Z., Hazan, R., Breker, M., Schuldiner, M. and Ben-Aroya, S. (2013). Formation and dissociation of proteasome storage granules are regulated by cytosolic pH. J. Cell Biol. 201, 663-671.

16 - Saunier, R., Esposito, M., Dassa, E. P. and Delahodde, A. (2013). Integrity of the Saccharomyces cerevisiae Rpn11 protein is critical for formation of proteasome storage granules (PSG) and survival in stationary phase. PloS One 8, e70357.

17 - Swisher, K. D. and Parker, R. (2010). Localization to, and effects of Pbp1, Pbp4, Lsm12, Dhh1, and Pab1 on stress granules in Saccharomyces cerevisiae. PloS One 5, e10006.

18 - Brengues, M. and Parker, R. (2007). Accumulation of polyadenylated mRNA, Pab1p, elF4E, and elF4G with P-bodies in Saccharomyces cerevisiae. Mol. Biol. Cell 18, 2592-2602.

19 - Finley, D., Ozkaynak, E. and Varshavsky, A. (1987). The yeast polyubiquitin gene is essential for resistance to high temperatures, starvation, and other stresses. Cell 48, 1035-1046.

20 - Mitchell, S. F., Jain, S., She, M. and Parker, R. (2013). Global analysis of yeast mRNPs. Nat. Struct. Mol. Biol. 20, 127-133.

21 - Teixeira, D. and Parker, R. (2007). Analysis of P-body assembly in Saccharomyces cerevisiae. Mol. Biol. Cell 18, 2274-2287.

22 - Stribinskis, V. and Ramos, K. S. (2007). Rpm2p, a protein subunit of mitochondrial RNase P, physically and genetically interacts with cytoplasmic processing bodies. Nucleic Acids Res. 35, 13011311.

23 - Tseng-Rogenski, S. S.-I., Chong, J.-L., Thomas, C. B., Enomoto, S., Berman, J. and Chang, T.-H. (2003). Functional conservation of Dhh1p, a cytoplasmic DExD/H-box protein present in large complexes. Nucleic Acids Res. 31, 4995-5002. 
24 - Sinturel, F., Bréchemier-Baey, D., Kiledjian, M., Condon, C. and Bénard, L. (2012). Activation of 5'3' exoribonuclease Xrn1 by cofactor Dcs1 is essential for mitochondrial function in yeast. Proc. Natl. Acad. Sci. U. S. A. 109, 8264-8269.

25 - Tudisca, V., Recouvreux, V., Moreno, S., Boy-Marcotte, E., Jacquet, M. and Portela, P. (2010). Differential localization to cytoplasm, nucleus or P-bodies of yeast PKA subunits under different growth conditions. Eur. J. Cell Biol. 89, 339-348.

26 - Tudisca, V., Simpson, C., Castelli, L., Lui, J., Hoyle, N., Moreno, S., Ashe, M. and Portela, P. (2012). PKA isoforms coordinate mRNA fate during nutrient starvation. J. Cell Sci. 125, 5221-5232.

27 - Li, L., Miles, S., Melville, Z., Prasad, A., Bradley, G. and Breeden, L. L. (2013). Key events during the transition from rapid growth to quiescence in budding yeast require posttranscriptional regulators. Mol. Biol. Cell 24, 3697-3709.

28 - Laporte, D., Salin, B., Daignan-Fornier, B. and Sagot, I. (2008). Reversible cytoplasmic localization of the proteasome in quiescent yeast cells. J. Cell Biol. 181, 737-745.

29 - Haslbeck, M., Braun, N., Stromer, T., Richter, B., Model, N., Weinkauf, S. and Buchner, J. (2004). Hsp42 is the general small heat shock protein in the cytosol of Saccharomyces cerevisiae. EMBO J. 23, 638-649.

30 - Smith, D. L., McClure, J. M., Matecic, M. and Smith, J. S. (2007). Calorie restriction extends the chronological lifespan of Saccharomyces cerevisiae independently of the Sirtuins. Aging Cell 6, 649662.

31 - Miller-Fleming, L., Antas, P., Pais, T. F., Smalley, J. L., Giorgini, F. and Outeiro, T. F. (2014). Yeast DJ-1 superfamily members are required for diauxic-shift reprogramming and cell survival in stationary phase. Proc. Natl. Acad. Sci. U. S. A. 111, 7012-7017.

32 - Talarek, N., Cameroni, E., Jaquenoud, M., Luo, X., Bontron, S., Lippman, S., Devgan, G., Snyder, M., Broach, J. R. and De Virgilio, C. (2010). Initiation of the TORC1-regulated G0 program requires Igo1/2, which license specific mRNAs to evade degradation via the 5' -3 ' mRNA decay pathway. Mol. Cell 38, 345-355.

33 - Narayanaswamy, R., Levy, M., Tsechansky, M., Stovall, G. M., O'Connell, J. D., Mirrielees, J., Ellington, A. D. and Marcotte, E. M. (2009). Widespread reorganization of metabolic enzymes into reversible assemblies upon nutrient starvation. Proc. Natl. Acad. Sci. U. S. A. 106, 10147-10152.

34 - Raju, K. K., Natarajan, S., Kumar, N. S., Kumar, D. A. and N M, R. (2015). Role of cytoplasmic deadenylation and mRNA decay factors in yeast apoptosis. FEMS Yeast Res. 15,

35 - Decker, C. J., Teixeira, D. and Parker, R. (2007). Edc3p and a glutamine/asparagine-rich domain of Lsm4p function in processing body assembly in Saccharomyces cerevisiae. J. Cell Biol. 179, 437449.

36 - Aragon, A. D., Rodriguez, A. L., Meirelles, O., Roy, S., Davidson, G. S., Tapia, P. H., Allen, C., Joe, R., Benn, D. and Werner-Washburne, M. (2008). Characterization of differentiated quiescent and nonquiescent cells in yeast stationary-phase cultures. Mol. Biol. Cell 19, 1271-1280.

37 - Chen, Q., Thorpe, J., Ding, Q., El-Amouri, I. S. and Keller, J. N. (2004). Proteasome synthesis and assembly are required for survival during stationary phase. Free Radic. Biol. Med. 37, 859-868.

38 - Wilms, T., Swinnen, E., Eskes, E., Dolz-Edo, L., Uwineza, A., Van Essche, R., Rosseels, J., Zabrocki, P., Cameroni, E., Franssens, V., et al. (2017). The yeast protein kinase Sch9 adjusts VATPase assembly/disassembly to control $\mathrm{pH}$ homeostasis and longevity in response to glucose availability. PLoS Genet. 13, e1006835.

39 - Buchan, J. R., Kolaitis, R.-M., Taylor, J. P. and Parker, R. (2013). Eukaryotic stress granules are cleared by autophagy and Cdc48/VCP function. Cell 153, 1461-1474. 